\title{
Firm Performance and Comply or Explain Disclosure in Corporate Governance
}

\author{
Rose, Caspar
}

Document Version

Accepted author manuscript

Published in:

European Management Journal

DOI:

10.1016/j.emj.2016.03.003

Publication date:

2016

License

CC BY-NC-ND

Citation for published version (APA):

Rose, C. (2016). Firm Performance and Comply or Explain Disclosure in Corporate Governance. European Management Journal, 34(3), 202-222. https://doi.org/10.1016/j.emj.2016.03.003

Link to publication in CBS Research Portal

\section{General rights}

Copyright and moral rights for the publications made accessible in the public portal are retained by the authors and/or other copyright owners and it is a condition of accessing publications that users recognise and abide by the legal requirements associated with these rights.

\section{Take down policy}

If you believe that this document breaches copyright please contact us (research.lib@cbs.dk) providing details, and we will remove access to the work immediately and investigate your claim.

Download date: 26. Apr. 2023 


\section{Firm Performance and Comply or Explain Disclosure in Corporate Governance \\ Caspar Rose}

Journal article (Post print version)

Cite: Firm Performance and Comply or Explain Disclosure in Corporate Governance. / Rose, Caspar. In: European Management Journal, Vol. 34, №. 3, २०१६, p. २०२-2२२.

DOI: http://dx.doi.org/10.1016/j.emj.2016.03.003

Uploaded to Research@CBS: June २०16

(C) 2016. This manuscript version is made available under the CL-BY-NC-ND 4.0 license http://creativecommons.org/licenses/by-nc-nd/4.0/

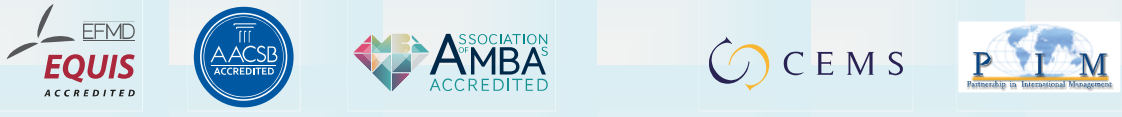


Firm Performance and Comply or Explain Disclosure in Corporate Governance 


\begin{abstract}
This study investigates the degree of Danish firm adherence to the Danish Code of Corporate Governance and analyzes if a higher degree of comply or explain disclosure is related to firm performance. This article formulates a methodology for quantifying the degree of comply or explain disclosure.

The analysis shows that there is a positive link between ROE/ROA and Danish firm total corporate governance comply or explain disclosure scores. Specifically, this is also the case when this level is increased within the following two categories: board composition and remuneration policy whereas there is no impact on performance when increasing compliance with the recommendations on risk management and internal controls. This article demonstrates that these three areas are the ones where Danish firms show the lowest degree of comply or explain disclosure although the overall adherence to the Danish code's many recommendations is relatively high.

This article relates to the burgeoning literature that deals with listed firm compliance with national corporate governance codes and how compliance can be appropriately quantified. It is suggested that compliance is classified into the following four categories: Complies, complies poorly, explains and explains poorly. The article demonstrates that measuring the degree of compliance cannot be done in a mechanical way. Instead, it must be customized to the respective national institutional environment, which suggests country comparisons will be difficult to make. The article contributes to the ongoing discussion of whether firms consider soft law to be a "tick the box" exercise or, alternatively, whether firms should work seriously with the recommendations in order to professionalize and increase competences among board members. The article's findings suggest that soft law may be an efficient way of increasing the quality of corporate governance among listed firms. However, in order to strengthen investor confidence, national code authorities/committees should be more active in penalizing poor explanations as well as cases when firms wrongfully state that they comply with a specific recommendation.
\end{abstract}

Keywords: Corporate Governance; disclosure; comply or explain; and firm performance

JEL Classification: G32 and G34 


\section{INTRODUCTION}

The "comply or explain" principle is a mandatory legal disclosure rule in all $28 \mathrm{EU}$ member states, from the extra-legal corporate governance code provisions that may be drafted by more or less independent bodies. The comply or explain principle was originally put forward by the Cadbury Committee in the UK as a practical way of establishing good corporate governance while avoiding the inflexible hard law "one size fits all" framework (see Seidl, Sanderson and Roberts (2013)). Even though national codes build on soft law, it is still debated if the voluntary nature of compliance is sufficient in promoting a higher degree of best practice among listed firms (see e.g. Aguilera and Cuervo-Cazurra (2009) for an overview and argument that the codes' voluntary nature may limit the ability to improve governance practices).

Most countries now have their own codes of corporate governance where various bodies have formulated specific recommendations based on the principle of comply or explain. These codes are issued by various bodies with a greater or lesser degree of state participation. For example, the UK Combined Code is issued by an independent regulator: the Financial Reporting Council (FRC). The French corporate governance codes are drafted by wholly private organizations (e.g. the AFEP-MEDEF code); the German corporate governance code is drafted by a government commission, which appoints independent members and the Danish corporate governance code is drafted by an independent body.

Several national codes have been inspired by the work of international organizations such as the OECD and the European Governance Forum. For an overview and discussion of the relevance of disclosure requirements, see Nowak (2008). The OECD first released its recommendations in 1999, which were later revised in 2004. The OECD Principles are one out of twelve key standards utilized to ensure the international financial stability of the Financial Stability Board. The recommendations form the basis for the corporate governance component of the Report on the Observance of Standards and Codes adopted by the World Bank Group. The OECD principles are currently under review in order to ensure the continuing high quality, relevance, and utility of the principles taking into account recent developments in the corporate sector and capital markets.

Corporate governance is essential in cases where there is a separation between ownership and control, especially in firms with dispersed ownership. Due to the free rider problem associated with dispersed ownership, 
shareholders do not have any incentive to challenge incumbent management, which grants top management a considerable amount of power. Dispersed ownership means that individual shareholders only hold a small ownership stake in a company. Any gains from active ownership must be divided among all other passive shareholders, despite the fact that the active shareholder bears all the costs. Thus, the incentive to challenge the supervisory/executive board may be limited.

One may define corporate governance as the ways and mechanisms, in which agency costs are minimized so that the interests amongst members of the supervisory/executive board and the shareholders are aligned, see Shleifer and Vishny (1997). Tirole (2001) argues for a broader definition that includes a wider range of stakeholders such as employees, creditors, customers, the local community etc. However, if agency costs are to be reduced, it is essential that investors are in a position to evaluate whether the board of directors follows acceptable corporate governance policies.

Corporate governance codes consist of recommendations that reflect best conduct practice and serve as national guidelines for publicly listed companies, highlighting transparency as a key corporate governance issue. However, as argued by Mintz (2005), such recommendations may be rendered meaningless unless internal controls are strengthened by senior management and accompanied by the adoption of an ethical tone by the board of directors.

The long-term performance effects of adhering to the recommendations may be difficult to isolate and quantify. However, it may still be relevant for managers and investors to assess whether there is a positive financial impact associated with the corporate governance recommendations; even if it is in the short-term.

Most Scandinavian corporate governance codes deal with issues such as board composition, transparency and remuneration. They may vary in size and structure, but they all focus on these important areas. To illustrate, the Finnish code is quite short and concise whereas the Swedish code is rather long and comprehensive. The Danish code seems to fit in somewhere in-between these examples.

Good corporate governance demands that investors and shareholders are confident that top management is serving the best interests of the company. This confidence lowers the agency premium, which may reduce the firm's cost of capital. Reporting on the corporate governance code serves transparency, but those standards may be specific to the viewpoint of a company. 
One may argue that a firm should not be punished if it offers an explanation why it has decided not to follow a specific recommendation. Yet, ultimately, it is up to the stock market to determine if the explanation is sufficient. This facilities a high degree of flexibility instead of excessively rigid hard law rules, which is highlighted e.g. in the UK Corporate Governance Code, see 'Whilst shareholders have every right to challenge companies' explanations if they are unconvincing, they should not be evaluated in a mechanistic way and departures from the Code should not be automatically treated as breaches."

The Danish management system consists of a supervisory board (bestyrelse) as well as an executive board (direktion). The supervisory board is responsible for controlling the executive board. The supervisory board must approve all decisions of significant importance. In addition, the Danish supervisory board is in charge of formulating the firm's strategy. The first Danish Corporate Governance code was issued in 2001 and it has undergone a number of revisions since. It builds on the "comply or explain principle", which means that a company must comply with a certain recommendation; otherwise the company must explain why it has decided not to follow what is considered "best practice."

This article presents a methodology for quantifying the degree of listed firms' corporate governance compliance. As recognized by Seidl et al. (2013), despite the wide application of the "comply or explain" principle, very little is known about the ways in which the principle is adopted by firms.

The value of good corporate governance rests on the presumption that "best practice" is not well defined or, in fact, is public knowledge. The development of the Danish corporate governance code is assigned to a special committee that consists of experienced board members and advisors. This implies that the code is revised on a continuing basis in order to ensure that the recommendations are regarded as best practice. This means that the committee consults academia and also analyzes what is considered to be best practice in other countries. The crucial question is whether corporate governance is able to facilitate a change in the mindsets of board members to the point where each board member feels a genuine alignment of interests with the firm's owners.

Best practice is not considered to be a universal tool that can bring a quick fix to a company's corporate governance structure. To illustrate, independent board members are vital in effectively monitoring executive 
management. Having the right mix between dependent and independent board members where the board works as a team with different competences is what matters if the board is expected to impact firm value.

This article is organized as follows. In the next section, the relevant literature is outlined and discussed. Section three contains a motivation for a number of hypotheses that link corporate governance comply or explain disclosure to firm performance as well as a brief description of the Danish corporate governance system. The methodology for assessing the degree of compliance is presented in section four.

The degree of comply or explain disclosure to the Danish code is presented in detail in section five which is followed by section six with a regression analysis of the relationship between comply or explain disclosure and firm performance. The article ends in section seven with a combined discussion and conclusion.

\section{LITERATURE}

The majority of the literature focuses on compliance. However, it should be noted that compliance is more than disclosure. Companies may disclose that they comply or not. The most precarious situation is when companies do not disclose that they do not comply. As a consequence, the following literature section is divided into the following subsections: 2.1. Compliance studies, 2.2 Disclosure studies and 2.3. Other contributions.

\subsection{Compliance studies}

The UK Code was revised in 2003 giving more prominence to the role of intendent non-executive directors in a company's corporate governance structure and decision-making process. Pass (2006) was the first to study the level of compliance with the new code. He found that in a sample of 50 large UK firms, 11 entities remained in breach of the code on one or more occasions. The author classified the firms' compliance into the following categories: fully complied, offered "acceptable" explanations, or in breach of the code.

One of the first other studies that analysed the relationship between company performance and compliance is Alves and Mendes (2004) who studied Portuguese listed firms. The Portuguese Code was issued in 1999 and was modelled on the OECD guidelines. The code includes 17 recommendations, which are directly related to firms, but it also contains two separate recommendations directed towards institutional investors. The analysis is based on dummy variables i.e. if a firm complies with a recommendation, it takes the value of 1 , and otherwise the 
value is zero. Their sample covers the years 1998-2001 and they document that the average degree of compliance has increased during the years. They find a positive relationship between compliance and corporate performance, where performance is measured as the risk adjusted return.

Werder, Talaulicar and Kolot (2005) conduct an analysis of 408 German listed firms' compliance with the German Code (analyzing 62 specific recommendations). Overall, they find that company size is positively associated with Code compliance. They specifically focus on the recommendations, which are expected to be most often rejected by more than $10 \%$ of the companies. The authors find that the German code has contributed to changes in corporate governance practice since the companies initiated adaptations to the recommended standards, which were not applied in the past.

Werder et al. (2005) conduct an extensive study of the German firms listed on the Frankfurt Stock Exchange covering 408 firms' compliance declarations. The German code consisted of 62 recommendations, but the authors focused on the 13 critical recommendations. These recommendations can be categorized into the following groups: Personal liability of board members, remuneration of the managing/supervisory board, staffing of the boards, the structure of the supervisory board as well as the choice of accounting principles. They show that the mean of the total number of non-compliance explanations equals 5,8 and that company size is positively related to the extent of code compliance. The overall result of their study is that German firms exhibit a higher degree of acceptance to the recommendations.

The study illustrates that regulation in the form of soft law may obtain a relatively higher degree of acceptance among listed firms, which highlights the "best practice" character of the corporate governance recommendations. According to the authors, the Code contributes to changes in corporate governance practices since companies initiate adaptations to the recommended standards, which were not applied in the past.

Goncharov et al. (2006) also study German firm compliance where the authors examine if there is a pricing effect associated with the declared degree of compliance for a sample of large publicly listed companies on the DAX30 and MDAX. They use a number of performance measures such as stock return, price change, earnings per share, as well as changes in earnings per share. 
They relate firm compliance with a number of explanatory variables, in which compliance is measured as a variable that equals one if the number of scaled deviations from the code's recommendations is less than the year median and zero otherwise. They find a positive relationship between performance and their measure of corporate governance compliance. Furthermore, they also focus on different forms of "explanation" for deviations. They find that a significant number of the deviations were either not justified at all or were justified on the basis of principled objections such as inappropriateness of code provisions, especially where both companies and investors consider a code provision fails to embody best practice.

The degree of corporate governance compliance can be done in a number of different ways. Akkermans et al. (2007) measure compliance in the following three ways: 1) A company can comply with a specific recommendation, 2) a company can explain why it does not comply with it, or 3) a company can make no reference to it at all.

The authors Talaulicar and Werder (2008) also study German firm compliance but their methodology is different as they rely on cluster analysis. Interestingly enough, the cluster solution does not merely reflect the number of rejected code recommendations. Companies with similar rates of overall compliance with the German Code are assigned to different clusters because they feature, at the same time, different patterns of code conformity. According to the authors, these findings imply that governance prediction and governance performance studies have to overcome overly aggregated measures of code compliance, which only incorporate the number of rejected code recommendations.

Saad (2010) analyses how listed firms in Malaysia comply with the Code of Best Practices established by the Malaysian Institute of Corporate Governance. Compliance is linked to a number of board characteristics as well as capital structure. Saad (2010) considers a large number of variables such as: dual leadership, board size, and board meeting, but finds only a significant relationship between compliance and a firm's capital structure.

Sanderson et al. (2010) explore the research carried out in the UK and Germany investigating the extent to which large public companies comply with the recommendations. They find that positive conformance with codes depends on factors such as the extent to which listed firms are engaged in the formation and revision of the code. 
The relationship between shareholder concentration and compliance with the German Corporate Governance Code is analyzed by Warning (2011). Based on data for publicly listed German firms, the empirical analysis shows that the effect of ownership concentration on compliance is inversely U-shaped. In other words, firms with very low or very high ownership concentration show a small probability of compliance while a moderate concentration leads to a higher degree of compliance.

One of the problems with the "comply or explain" principle is that some firms may provide explanations that are poorly justified. This issue is addressed by the authors, Arcot et al. (2010) who study the effectiveness of the principle using a unique database of 245 non-financial UK firms for a period of six years. Even though they find an increasing compliance trend, they highlight the common use of poor language when explanations are given. Thus, they argue that the 'explain' part of the Code is ineffective. Specifically, they compile a ratio of the frequency of specific explanations to the frequency of non-explanations for eight provisions. This ratio is used to assess the relative value of the "comply or explain" principle compared to the statutory approach. They show that the estimated ratio is the lowest for the provisions relating to the one third of non-executive directors, majority of independent non-executive directors, and composition of the remuneration committee, suggesting that the value of flexibility is the lowest for these provisions.

A study by Renders et al. (2010) also documents a positive relationship between performance and corporate governance compliance. Their methodology addresses the classical endogeneity problem, which is widespread in many corporate governance studies by using instruments and 2SLS. An instrument is correlated with the endogenous variable but is not correlated with the error term i.e. it is exogenous. Any variable that is thought to be exogenous and independent of the disturbance is retained to serve as an instrument.

The classical example is the study of a person's wage and education. There is often a high correlation between a person's education and his/her parents' education, but since parental education does not influence a person's wage, this variable may serve as a suitable instrument. Instruments are used when two stage least squares are carried out. However, the authors also recognize that it is hard to find good instruments. This study is interesting because it includes a large panel dataset covering 14 European countries from 1999-2003 using 1.199 firms/firm observations. The sample consists of FTSEuropfirst300 and the vast majority of firms are from the UK. 
As a measure of the degree of compliance the authors use Deminor Rating. Every year, Deminor assesses the largest 300 European companies included in all the major indices. The ratings are based on a corporate governance grid comprising over 300 criteria. As mentioned, the authors find a positive significant relationship between corporate governance ratings and performance. Even though the authors find a positive significant relationship, one should be careful to uncritically use a private consultant firm's corporate governance ratings. These ratings may not take into account the large institutional as well as legal variances that exist between different countries. Moreover, there is no sufficient documentation on how these ratings have been carried out and validated. To ensure a sound and valid dataset, one also needs to be very consistent and precise about the methodology used. Nevertheless, their study is clearly interesting as it builds upon an advanced modelling approach that may inspire future econometric work on corporate governance compliance.

Hooghiemstra and van Ees (2012) study the compliance of 126 Dutch firms analyzing nine types of motivations for non-compliance. They find that firms frequently justify a deviation from external standards by revealing their internal practices instead. Thus, the authors document a uniform way of adopting the standards of good corporate governance, which is not in line with the logic or meaning of the code and it casts doubt on the effectiveness of soft law. As a consequence, the authors indicate that more restrictive regulatory instruments may be necessary to make firms conform to the spirit of the codes.

The authors Gutierrez and Surroca (2012) conduct a study on the Spanish corporate governance system. They argue that the system, which evolved in Spain, does not fit with these two seemingly mutually exclusive models. Instead, they argue that Spain has evolved towards a hybrid model. Specifically, they analyse managerial incentives, control structures, board committees, ownership structures, and the market for corporate control, labor as well as product markets. Their sample covers the IBEX 35 companies over the period 2005-2007 that are obliged to follow the Spanish corporate governance codes i.e. the Olivencia Code, Aldana Report and the Unified Code. It is interesting to note that according to the authors, a special feature of the Spanish system is the existence of binding definitions. Listed companies can freely decide to comply or not with the codes' recommendations, but in their reporting of fulfilment they must invariably respect the underlying concepts used. 
Gutierrez and Surroca (2012) document that recommendations which are not followed by more than $25 \%$ of companies fall within the following categories; use of different board committees, information about business transactions by the executive committee, board independence, $\mathrm{CEO} /$ chairman duality, number of board members, the issue of gender and disclosure of individual CEO remuneration.

Seidl et al. (2013) conduct an analysis of 257 listed firms in the UK and Germany where they examine the underlying logic and identify various legitimacy tactics and their implications for policy makers. Seidl et al (2013) argue that legitimacy theory is the relationship between the organization and its audiences. According to the authors, legitimacy theory is not about the structures or actions of a company per se, but rather the particular relationship with its audience. This entails that every company will try to ensure that its audience perceives its actions and structures as desirable, proper or appropriate. One may challenge their notion that any theory is a relationship. Instead "A theory is a generalization about a phenomenon, an explanation of how or why something occurs" Frey et al. (1991) or "a way of making sense of a disturbing situation," Kaplan (1964), whereas "legitimacy is a generalized perception or assumption that the actions of an entity are desirable, proper, or appropriate within some socially constructed system of norms, values, beliefs and definitions," see Suchman, (1995), p. 574.

Seidl et al's analysis is based on the UK combined code as well as The German Cromme Code. The two codes consist of 48 and 82 code provisions, respectively, and the authors use \%\%ages instead of absolute numbers when they analyze firm compliance. The authors derive a grounded taxonomy of different "explanation" deviations. Specifically, they find that a significant number of deviations were either not justified at all or were justified on the basis of principled objections such as appropriateness of code provisions.

As noticed by the authors Shrives and Brennan (2015), there are no regulations about explanations for noncompliance, as it is up to the market to judge these explanations. The authors develop a typology to assess the quality of corporate governance explanations. They study non-compliance of the UK FTSE 350 companies in two accounting periods based on seven quality characteristics: location, comprehensiveness, mimic behavior, length, complexity, specificity and attestation. They find that even though compliance increased over the period, explanations were found to be of variable quality. 
Specifically, they argue that companies could improve their explanations, especially within location, complexity, and specificity emphasizing that better explanations are more important than compliance.

The link between compliance and financial performance is studied by Tariq and Abbas (2013) who evaluate the efficacy of the Pakistani Code of Corporate Governance using a panel of 119 firms during 8 years. They construct a score on each requirement that ranges from zero to five depending on the quality of information reported. Given that all clauses are applicable to a firm each given year, the score ranges from a minimum of 101 to a maximum of 501. Performance is measured by ROA, ROE, ROCE (Return on Capital Employed), as well as EPS. They find a significant positive link between compliance and financial performance.

\subsection{Disclosure studies}

Nelson (2005) examines the link between firm performance, CEO characteristics, and changes in corporate governance practices based on a large sample of US firms from 1980 to 1995 . Specifically, he finds that shareholders are more likely to approve an increase in the power of the board of directors of better performing firms, while the board of poorly performing firms are much more likely to initiate governance changes—such as poison pills-which circumvent shareholder's approval. A poison pill is a widespread takeover defense that dilutes a hostile acquirer's stock holding if a certain level of ownership is triggered. The author makes an interesting documentation of the many various takeover defenses that are applied by US firms.

De Jong et al. (2005) analyze the relationship between firm value (using Tobin's Q) and corporate governance characteristics before and after the corporate governance recommendations in the form of soft law in the Netherlands (The Tabaksblatt Code). The authors find that the private sector's soft law initiatives had no effect on corporate governance characteristics or firm value. The authors argue that if such initiatives are to be successful, monitoring must be supported by enforcement.

The issue of corporate governance compliance from a European Perspective has also been addressed by Vander Bauwhede and Willekens (2008) who study compliance disclosure based a sample of FTSE Eurotop 300 companies. Their final sample includes 130 companies and they rely on the compliance rating provided by a private rating firm i.e. Deminor Rating. 
They test a number of hypotheses, including the relationship between legal origin and the degree of compliance where they test if Non-Common law countries disclose less corporate governance information compared with firms in Common law jurisdictions. The authors examine the factors that influence the level of disclosure on corporate governance by European companies preceding the Jaap Winter recommendations. Prof. Jaap Winter was Chairman of the High Level Group of Company Law Experts initiated by the EU Commission. The authors document some interesting findings such as that the level of disclosure is positively related to the degree of separation of ownership and control as well as the degree of uncertainty in reported earnings (accruals). Vander Bauwhede and Willekens (2008) also find that the level of corporate governance disclosure is significantly lower in Non-Common law countries, compared to Common law countries. However, the authors do not find a significant relationship between debt and the degree of corporate governance disclosure.

Executive remuneration has been the subject of much attention among investors and the media. Transparency regarding executive remuneration is a key feature in corporate governance codes. Andres and Theissen (2008) study the level of individual remuneration disclosure among German listed firms in the years 2002, 2003 and 2005. Interestingly enough, they find that firms which paid higher average remunerations to their executive board members were less likely to comply with the recommendation to disclose remuneration on an individual basis. Thus, firms with higher Tobin's Q were more likely to comply. Moreover, their methodology avoids conceptual difficulties of measuring disclosure quality and linking it to effectiveness, because they confine their research to easily verifiable disclosures. They analysed a German code norm (recently obsolete) which recommended individualized remuneration disclosure. The individualization of remuneration disclosure is easily verifiable, not, of course, the reported remuneration methods and amounts.

The degree of compliance on a country level has been analysed in several studies. Dyczkowska (2012) studies Polish-listed firms compliance focusing on the importance of an investor relation function. Dyczkowska (2012) shows, that Polish firms do not follow all the recommendations even though Polish firms are aware of the importance of open and effective communication with investors. Specifically, the majority (61\%) of the companies neither provided live online broadcast of the annual general meeting, nor did 37\% publish shareholder queries related to agenda matters at the general meeting with answers to the questions on their 
corporate website. A similar group $(30 \%)$ did not maintain their corporate websites in English regarding corporate governance matters.

Bozec and Dia (2012) explore the corporate governance practices of Canadian companies focusing on whether the convergence phenomenon evidence in prior studies is limited to mandatory requirements imposed by regulators or whether it reflects real behavioral transformation. The authors show that Canadian firms improved their corporate governance practices in the post-Enron period mainly in areas mandated by regulation such as composition, attributes and the functioning of the board of directors and board committees. The authors find no significant improvement in non-regulated governance best practices, suggesting no real behavioral change among corporate leaders. These results are less encouraging as they indicate that convergence in corporate governance appears to be the result of a box-ticking exercise.

Seidl et al. (2013) document that the most frequent deviations in the UK concerned the following issues: the requirement for a majority of the board to be independent non-executive directors, the composition of the audit and remuneration committee, respectively, as well as the requirement for the majority of the members of the nomination committee to be independent. The provision with the highest level of deviation in Germany was quite different from that of UK companies i.e. requiring individualized disclosure of compensation to the management board members followed by agreeing upon a suitable deductible for the $\mathrm{D} / \mathrm{O}$ insurance policy and requiring the individual disclosure of compensation to the supervisory board members.

\subsection{Other contributions}

Traditionally, the classification of corporate governance systems has been characterized as either belonging to the market/shareholder model (Anglo-American countries) or the bank-oriented/stakeholder model (typically in non-Anglo-American countries), see Becht and Roel (1999). The impact of legal origin on financial development has been explored widely within corporate governance; see La Porta et al. (2000). Zattoni and Cuomo (2008) explore the notion of legal origin and national corporate governance codes between the Common and Civil law countries. They find that the issuance of codes in civil law countries may be prompted by legitimate reasons rather than by a determination to improve the governance practice of national companies. 
Moreover the authors find that all codes of good corporate governance contain principles on board composition and independence with the exceptions of an employee's role, conflict of interest, deontology of directors and board directorships.

The authors Fernandez-Rodriguez et al. (2004) study Spanish firms, but they rely on event study methodology in which they measure if there are any abnormal stock market returns resulting from the announcements made by Spanish firms to comply with the Olivencia Code. Their results show that the market reacts positively to announcements of compliance with the code which emphasize a major restructuring of the board of directors, whereas no stock market effects are observed in relation to isolated announcements.

The authors rely on an event window of $+/-20$ days, which is a quite long period of time. They find that these stock market effects are greater for lower financially leveraged firms and also greater for firms with a higher $\% \%$ age of executive directors. These findings are based on a cross-sectional regression where they regress a number of explanatory variables against the cumulative abnormal return vector.

Moreover, Shnitser (2010) conducts an interesting empirical analysis of the enforcement of U.S. securities laws regarding foreign issuers. Proponents of the bonding hypothesis argue that foreign firms cross list in the US in order to signal a higher degree of compliance by following the stricter US Corporate Governance regime. The author finds that relative to domestic issuers, foreign issuers in the US have benefitted not only from a more lax set of rules, but also from a forgiving public enforcement agency. At the same time, US courts have limited private enforcement against foreign issuers, thus restricting an alternative to public enforcement and further widening the gap between the corporate governance regime for US issuers and the regime for foreign issuers.

Fasterling (2012) discusses norms through compliance disclosure identifying weaknesses that prevent them from becoming effective mechanisms to discipline a certain type of behavior. Specifically, it may be argued that the comply or explain principle may mount a façade of corporate conformity, or serve as a tick the box exercise instead of disclosing the company's bona fide assessment of a norm proposal's application to the individual circumstances of the company. 
This article seeks to establish a link between corporate governance disclosure quality and firm performance. Some authors argue that such an approach may be difficult to establish. In fact, Bhagat, Bolton, and Romano (2008) argue that the effectiveness of using corporate governance indices in prediction performance may suffer from methodological shortcomings. Specifically, their conclusion is that there is no consistent relationship, as there is no one "best" measure of corporate governance and that the effective governance system depends on the context and the firms' specific circumstances. There is no doubt that it is difficult to establish such a relationship, but nevertheless this article seeks to make an attempt to demonstrate a link using a new methodology to quantify compliance disclosure.

\section{HYPOTHESES}

This article seeks to fill an important research gap between a firm's level of corporate governance comply or explain disclosure and firm financial performance measured by ROA and ROE. Financial performance is not difficult to measure, but the association between the degree of corporate governance comply or explain disclosure and performance is insufficiently developed as the prior literature section reveals. One reason is that it is not clear in the literature how corporate governance comply or explain disclosure may be properly quantified. $\mathrm{ROA}$ and $\mathrm{ROE}$ are the most frequent financial performance measures in the literature, as they measure firm profit in relationship to the total employed resources/assets as well as shareholders' equity.

Proponents of soft law argue that this approach in comparison to hard law recognizes that "one size does not fit all" by providing firms with a higher degree of flexibility. Others are more sceptical and argue that the benefits of flexibility and the self-regulatory status of the codes are overstated and that the code should be integrated into mainstream company law, see MacNeil and Li (2006). The authors conduct a study of British company compliance with the Combined Code focusing on the nature of explanations that have been given by companies with an established record of non-compliance and the role of the market in permitting these deviations. They find that it appears that investors' tolerance of non-compliance is linked to some extent with superior financial performance in terms of share price changes. 
However, the authors also address a key issue associated with non-compliance i.e. how this issue is monitored and excused. In most cases, this task is put in the hands of the individual stock exchanges. In the Copenhagen Stock Exchange (NASDAQ OMX Nordic), companies with a very low degree of compliance are contacted informally and encouraged to increase their compliance. Official sanctions have not yet been imposed for seriously inadequate corporate governance compliance. In the Netherlands, non-compliance in the form of silence regarding the best practice is illegal; see Akkermans et al. (2007) although the authors identify firms which neglect reporting non-compliance with one or more best practice provisions.

Increased compliance very often entails higher costs, as firms must devote time and effort to adhere to the standards of "best practice". To illustrate, Sneller and Langendijk (2007) conduct a case study where they analyze the costs of compliance with Section 404 in the Sarbanes Oxley Act (SOX). They find that the internal hours spent on assessment are 12 times higher than the initial estimate by the SEC in 2002. Thus, they also show a year- by- year increase of $50 \%$ of the company's audit fee in the first year of section 404 compliance. The authors suggest that companies can reduce the costs of compliance by implementing programmed controls, using auditors from countries with lower rates, only remediating material weaknesses, focusing on the internal control system rather than individual controls and by encouraging the auditor to rely on the company's assessment.

One may not directly compare the costs of adhering to the SOX requirements of internal controls, but one should not neglect the fact that increased corporate governance compliance is not without cost and is associated with considerable effort. The key issue is whether increased corporate governance comply or explain disclosure is beneficial in the long run by increasing transparency and corporate governance quality i.e. if the benefits exceed the costs, which leads to the following main hypothesis.

H1: Increasing the level of corporate governance comply or explain disclosure is positively associated with performance

As mentioned, international organizations such as the OECD have also been active in promoting the debate on good corporate governance by issuing their own guidelines. Tsipouri and Xanthakis (2004) discuss if corporate 
governance can be rated in the first place discussing interesting methodological issues such as the creation of the "collectively subjective" weighting.

Specifically, the authors address whether there are benefits from separating the rating of the market form the rating of companies. The authors were some of the first to make an attempt to quantify the corporate governance compliance of listed firms. They study how Greek companies relate to best practice based on the OECD recommendations. They find that Greek companies demonstrate a fairly satisfactory degree of compliance, with the exception of the role of stakeholders, CSR, the effective role of independent board members, disclosure of remuneration, as well as risk management.

Some recommendations may be regarded as more important than others and one may expect a lower degree of compliance with "critical" issues such as board composition and CEO remuneration. To illustrate, Akkermans et al. (2007) study Dutch firm's compliance with the Tabaksblat Code indicating a high level of compliance. However, they note that provisions related to remuneration of board members, independence of supervisory board members and requirements with respect to internal control systems stand out when it comes to noncompliance. As a consequence, this article specifies a number of sub-hypotheses in order to analyze the impact of different corporate governance categories.

H1.1 Increasing the level of corporate governance comply or explain disclosure regarding board composition is positively associated with performance

Board composition is central to corporate governance, as board members must monitor daily executive management on behalf of the firm's shareholders. Inadequate organization of the board's work may hamper the ability to control the CEO and other top executives. The board members' skills and competences are vital in this respect, so by relying on an efficient and transparent selection process for new board candidates, strong CEOs may engage in less risk taking and might be challenged when planning major strategic decisions.

Normally, one distinguishes between the one and two- tiered board systems. As mentioned, the Danish system does not fall entirely into either of these groups. 
The supervisory board members are elected at the general meeting. Contrary to e.g. Germany, the Danish supervisory board has the discretion to make decisions in cases of major importance and also carries responsibility for the firm's overall strategy.

The Danish code contains a large number of recommendations regarding the composition and organization of the supervisory board, including board composition, training, size, degree of independence, number of meetings, the period of election and guidelines for retirement. The code also contains a number of recommendations regarding the use of board committees, which are regarded as positive, since best practice may increase efficiency and improve the quality of the work performed. This includes the use of remuneration, nomination, as well as audit committees in which the supervisory board can be assisted in the preparation and processing of the material on which decisions are based. Compliance with the code may ensure that the supervisory board is organized in an effective manner, which results in more efficient monitoring of executive management. This may also increase the board's understanding of more complex issues such as structuring sound incentive contracts. See e.g. Viral et al. (2000) regarding the issue of resetting executive stock options. At the same time, following the board composition recommendations may strengthen the board's ability to formulate and execute a sound strategy for the firm, which may influence performance positively.

H1.2 Increasing the level of corporate governance comply or explain disclosure regarding managerial remuneration is positively associated with performance

After the financial crisis erupted, much attention has been paid to managerial remuneration, in particular the use of incentive contracts in the form of stock options. Critics argue that strong CEOs are able to negotiate favorable contracts at the expense of the firm or that such contracts provide incentives for management to engage in excessive risk taking thereby maximizing short term return, see Bebchuk et al. (2011), Morse et al. (2011) and Laux (2012). To illustrate, powerful CEOs who have been granted stock options may engage in costly mergers and acquisitions instead of relying on organic growth, see Jie and Vijh (2007) as well as Masulis et al. (2007).

From a theoretical perspective, it has been argued that incentive contracts are necessary to align the interests between top management and their owners, since shareholders are not able to monitor management efficiently 
on a continuing basis (see Holmstrom (1979) \& Grossman and Hart (1983)). Incentive contracts are therefore viewed as a substitute for monitoring (Hall and Murphy (2003); Garvey and Milbourn (2006)).

From a more practical perspective, proponents argue that incentive contracts are vital in order to attract, motivate and maintain highly qualified top managers, see Adams et al. (2005) for analysis of firm performance and powerful CEOs.

The Danish recommendations focus on a number of key issues in relation to managerial remuneration, especially variable pay. To illustrate, it is mentioned that limits are set on the variable components of the total remuneration package. The code also emphasizes that there should be a reasonable and balanced linkage between remuneration for executive body members and expected risks as well as value creation for shareholders in the short- and long-term. The code also recommends that there should be clarity about performance criteria and measurability for the award of variable components, including criteria ensuring that the vesting periods for variable components of remuneration agreements are longer than one calendar year. The recommendations are fairly detailed and elaborate. On the contrary, the code is rather vague with regard to the total remuneration. It only mentions that the total remuneration should be reasonable and reflect the executive body members' (executive board) independent performance, responsibilities and value creation in the company.

One would expect that if supervisory board members are able to design a remuneration contract that is balanced and aligned with the interests of the shareholders this might have a positive impact on firm performance. The worst case is a "reward for failure" situation, where executive management is financially rewarded even when a firm does not add value to its shareholders or even when a firm's value has been destroyed.

One may argue that by adhering to the Codes recommendations or alternatively by providing convincing arguments if a firm deviates from a specific recommendation on managerial remuneration, that this might stimulate firm performance. Alternatively, investors may punish the firm by selling their shares or by asking critical questions at the AGM.

H1.3 Increasing the level of corporate governance comply or explain disclosure regarding internal controls and risk management is positively associated with performance 
Without proper risk management as well as internal control processes, there is a risk that key employees may be tempted to engage in fraudulent activities or that the annual report will be manipulated by executive management. Sufficient internal controls and risk management systems are vital in connection to the financial reporting process. It is important that the external auditor is independent and competent, but it is pivotal that the supervisory board has a close and confident relationship with the external auditor. This entails having a regular dialogue and exchange of information with the auditor, an external chartered accountant. Specifically, it is recommended in the Code that the supervisory board and the audit committee have meetings with the auditor at least once year without the CEO, including the internal auditor.

The Danish code only contains four specific recommendations on risk management and internal controls. The four recommendations are: identification of key risks, reporting on risk development, whistleblowing and openness about risk management. However, focusing on efficient financial reporting is essential for monitoring executive management as well as evaluating the financial consequences of strategic decisions. Irregular or inadequate internal controls in the organization may also increase the risk of being fined e.g. for bribery, corruption, dominant market behavior, cartel cases and violations of other public compliance obligations. All these events may have a significant negative impact on firm performance.

Denmark formalized its first corporate governance recommendations in 2001 in a paper entitled "the Nørby report," named for its chairman. Since then, the recommendations have undergone several revisions and adjustments following, for example, the modernization of the Danish Company Act in 2010 and the adoption of EU recommendations.

The Committee emphasises the voluntary nature of its recommendations c.f. "Thus, non-compliance is not inconsistent with the spirit of the recommendations, but merely a result of the fact that the company has chosen a different approach. The markets must decide whether deviations are indeed justified. The Committee finds that self-regulation is the best form of regulation when it comes to corporate governance," see the Danish code (2010). Further information about the Danish Corporate Governance Committee and its Code's nine sections maybe found in the appendix. 


\section{DATA AND METHODOLOGY}

This article assesses the governance practices associated with the Danish corporate governance recommendations introduced in April 2010. The governance recommendations apply to all listed companies with fiscal years ending in 2010 or mid 2011 (hereafter; fiscal year 2010). Thus, this article addresses the fiscal year 2010 (ranging from the calendar year 2010 as well as the period mid 2010/2011)

When assessing the companies with respect to corporate governance practices, the analysis relies on publicly available information. The main sources of information include reported governance practices and relevant material on the companies' web pages including annual reports for the fiscal year 2010. The data has been collected manually over a period of two years.

The framework consists of nine main chapters containing 78 recommendations in total. Out of these 78 recommendations, it has been decided to exclude seven of the recommendations due to their overlap with current legislation or overlap with content embedded in another recommendation. Thus, the analysis concerns comply or explain disclosure with 71 of the recommendations. Since the number of recommendations is sufficiently large, it has been determined that the exclusion of a small number of recommendations does not impact the overall conclusions of the analysis.

All companies have been assessed based on how they communicate their governance practices using a binary scale of 0 or 1 point for each recommendation. If a company has chosen to comply with a given recommendation and this can be verified, the company receives a score of 1 (denoted: Complies). If a company claims to comply but its practice proves otherwise it receives a score of zero (denoted: Complies poorly). Companies that have chosen not to comply with a given recommendation are given a score of 1 if the explanation is accompanied by a reasonable argument (denoted: Explains). Finally, if a company does not explain why a recommendation has not been followed, or if the explanation does not seem justified, a score of 0 is given (denoted: Explains poorly).

The maximum score a company can receive is therefore 71 , equivalent to the number of analysed recommendations. Most recommendations are divided into sub recommendations, but since each of these sub recommendations is considered equally important to those with only a single recommendation, it has been 
decided to treat them all equally, and hence they each count as one. This is also to avoid a discussion of the relative importance or weighting of the different recommendations.

One may argue that the classification process for the four categories introduces the risk of a researcher's bias. Even though all efforts have been made to avoid subjectivity when assessing comply or explain disclosure, it cannot be ruled out that another researcher may reach a slightly different result. However, it is believed that this would not alter the analysis significantly.

The different recommendations vary considerably in nature. Some are easily verified due to being very specific with respect to disclosure, while others are more difficult to verify. This means that a company which claims to be compliant with a non-verifiable recommendation cannot be penalized since it cannot be checked if the compliance statement is in fact true. Companies that have chosen not to comply with such recommendations can be given the score 0 if their explanations are not sufficient.

There were a total of 188 companies listed on Nasdaq OMX Copenhagen. This total sample is restricted to 155 companies. There are five main reasons for this. 1) Some companies are listed with two share classes. 2) Some companies are listed as separate entities, but are in essence organized in a very similar manner. To illustrate, Formuepleje/FormueEvolution consists of a series of listed companies where the main difference is their investment profile. To include all Formue companies would have yielded the same result for all companies, thus resulting in a total sample score skewed disproportionately towards the score of these companies. 3) Some companies have been liquidated or taken private before gaining access to their governance practices, so information was no longer available. 4) Some companies are also listed in other countries, and have therefore chosen to adhere to other governance frameworks.

There are single companies that follow Swedish recommendations whereas there is one firm each that follows Icelandic, UK and Malaysian recommendations respectively. 5) A very small number of companies were communicating their governance practices so poorly that it was impossible to make sound assessments. It has not been possible to find two firms' corporate governance policies, so it is impossible to assess how they comply/explain. Including these companies would arguably have lowered the average result, but it is the impression that these companies are not representative of the sample. 
To ensure the highest validity possible, all companies have been contacted via e-mail and presented the recommendations where they had been given a score of 0 . The companies were given the opportunity to respond, and argue their case if they believed the evaluation to be incorrect. When feedback was received a reassessment of the initial scores was carried out. This resulted in a change of the scores accordingly if it was agreed that the arguments had any merit and if they could be documented. In order not to favour companies who responded, there was also a reassessment for all other companies who had been given 0 with respect to these recommendations. The response rate was less than five $\% \%$. In all cases, it was observed that only firms with relatively low corporate governance scores responded. As such, there is an inherent bias in the response rate, as high complying firms rarely responded. However, in a very few cases, we had to change the original assessment. To illustrate, an example of a good explanation is the following (provided by S.P. Group): "The board believes that an age-limit is discriminating, and also that capacity and contribution is more important than age". On the other hand, the following are examples of inappropriate explanations. For example, the firm Brd. Klee stated that "The company has decided that there is no age limit" and the firm TopoTarget noted that "The company follows the practice of comparable companies".

Contrary to the European Commission, the Danish Committee has not issued criteria for the quality of explanations for non-compliance", which is surprising, as the European Commission did issue a recommendation with relatively detailed criteria, see COMMISSION RECOMMENDATION of 9 April 2014 on the quality of corporate governance reporting ('comply or explain') (2014/208/EU).

The following pages present the scores given to the individual recommendations for the entire sample. The figures below measure the $\% \%$ age of companies on the vertical axis, and the respective recommendations on the horizontal axis. The reader should note that the vertical axis is truncated in all figures in order to make the figures easier to read. Also, results for the recommendations 4.1-4.3 (part of board responsibilities) and chapter 7 (Financial Reporting) are not shown, as all companies comply and score 100\%.

Each column in the following figures incorporates up to four different assessments of the companies' attitude towards the respective recommendations, and each column sums $100 \%$. The list below describes each of the four categories: 
- $\quad$ Complies $=$ Companies that comply with the recommendation, 1 point.

- Complies poorly $=$ Companies claim to comply, but in fact do not, 0 points.

- Explains $=$ Companies that do not follow the recommendation and explain well, 1 point.

- Explains poorly $=$ Companies that do not follow the recommendation and explain poorly, 0 points.

\section{[INSERT TABLE 1]}

Table 1 presents the overall result with respect to the four categories. The total number of recommendations $(11,005$, bottom line) is equal to the number of firms multiplied by the number of recommendations (155 companies $x 71$ recommendations). On an aggregate level the number of recommendations that were categorized as "complies poorly" is approximately equal to the number of "explains poorly".

\section{COMPLY OR EXPLAIN DISCLOSURE RESULTS}

This section presents the empirical results of the Danish listed companies compliance with the Danish Corporate Governance Code. In figure 1 the distribution of total scores regardless of firm characteristics is presented.

\section{[INSERT FIGURE 1]}

Most companies are situated in the upper level of the scale, and the median score is 66. Thus, half of the companies receive scores between 66 and 71. The high scores indicate that Danish listed companies actively relate to the recommendations in a rather positive manner. The distribution is not at all symmetric, but rather skewed to the right. $7 \%$ of the companies have a maximum score since they relate to all the 71 recommendations. More than $9.5 \% \%$ of the companies comply with all except a single recommendation. Approximately $46 \% \%$ of the companies only miss 5 to 1 recommendations, which must be regarded as a high comply or explain disclosure degree given the large number of Danish corporate governance recommendations.

The overall impression is that the vast majority of Danish firms either comply or alternatively explain adequately why a given firm has decided not to follow a specific recommendation.

\section{[INSERT FIGURE 2]}


Figure 2 shows how the three different size segments score in each of the nine main chapters/categories, as well as the average score for all companies. Large-caps receive higher scores than the two other segments in five of the nine chapters, and mid-caps perform better than the other segments in two of the nine chapters i.e. Role of stakeholders and Transparency. Small-caps perform the worst in all chapters, except in chapter 1 where smallcaps perform marginally better than mid-caps, as well as in chapter 7 on financial reporting where all three segments score $100 \%$.

The equally weighted average score for all companies is generally much closer to the score of the small-caps than the other segments. Due to the large number of firms in the small-cap segment, relative to the two other segments, this is not surprising. However, figure 2 reveals that the latest and newest chapter on risk management and internal controls shows a relatively low score of nearly $87 \% \%$ on average where especially small cap firms tend to be less concerned about the four recommendations regarding audit issues. This is contrary to the large cap firms that to a very large extent relate to the audit recommendations.

Figure 2 shows that relatively many firms do not relate to the recommendations regarding: Role of Stakeholders, Composition of the board, and Remuneration policy, which is especially the case for smaller companies. Moreover, figure 2 illustrates that there is a large variation among the different chapters, including among the three stock market segments. On the other hand, all firms tend to either comply or to explain fully concerning: Risk Management and internal controls as well as Responsibilities of the board. This is quite positive, as these two topics are highly relevant to corporate governance. Following the financial crisis, the vast majority of listed firms, not only financial firms, have realized that having sound risk management policies and internal controls are vital. To illustrate, there have been several international incidents where investors have been exposed to fraud or rogue trading in financial institutions, which naturally has made these issues a top priority on board agendas.

Responsibilities of the board include overall tasks and responsibilities and procedures such as the role of the chairman and deputy chairman. As mentioned, firms score very high on these issues and this might be due to the relative straightforward nature of these recommendations, which are considered less "demanding" for firms.

Following the controversial public debate on director remuneration, it interesting to note that the score in chapter 6 on Remuneration policy is relatively low, especially considering the attention paid to remuneration 
issues in the Danish Code. Moreover, The EU has issued a recommendation on managerial pay and introduced binding laws on remuneration when changing the capital directive and financial institutions directive. All EU legislative initiatives have been implemented into Danish law. Specifically, very strict rules on incentive based pay for individuals who are considered as leading risk takers have been imposed on Danish listed banks.

These rules must be seen in combination with the relatively new company law rules, which require the board to receive shareholder approval for overall incentive contracts. Therefore, it is surprising that the small cap firm score is relatively low on these matters, especially since mid and large cap firms both score high.

\section{[INSERT FIGURE 3]}

Regarding the composition of the board, there are particularly two recommendations where companies score very poorly: 5.1.1 and 5.1.4. in figure 3 .

"5.1.1... recommends that the supreme governing body annually specify the skills it must have to best perform its tasks and that the specification be posted on the website."

$30 \%$ claim that they are following this practice, whereas they in fact do not. It can often be observed that a CV of the current board members is the only board-related information available. Also, $26 \%$ have chosen to deviate from this recommendation, without sufficiently explaining why this practice is chosen. It should be noted that the figures sum up to $100 \%$ since the figures have been rounded.

"5.1.4... recommends that every year, the management commentary in the annual report contain an account of the composition of the supreme governing body, including its diversity, and of any special skills possessed by the individual members."

For this recommendation it has been chosen not to judge practices related to diversity. Instead companies have been scored by their practice related to communicating individual board member competencies. $39 \%$ of the companies claim to comply, but do not articulate specific competencies in their annual reports.

Rather there is a tendency for these companies to just list formalities, such as other occupations e.g. other board or managerial positions and education. 
It may be argued that competencies may be inferred from such information, but clearly expressing exact competencies arguably gives the impression of a more transparent approach.

\section{[INSERT FIGURE 4]}

According to 5.4.1 at least half of the board members should be independent with respect to some observable criteria c.f. figure 4 . Approximately $16 \%$ have chosen not to follow this recommendation, with the majority of these companies explaining their reasons quite well. A common and reasonable explanation is related to the ownership structure, where typically a shareholder due to the possession of voting rights can determine on a stand-alone basis, which members are going to be elected.

5.5.1 recommends that the system of employee-elected board members be explained in the annual report or on the webpage. $10 \%$ claim to practice this, without actually providing a description of the system, except for noting that employee representatives are present on the board. While $25 \%$ explain quite well why they do not provide a description of the system: either they do not have employee elected board members, or the majority of the shareholders are Danish and are assumed to be familiar with the system.

5.6.1 states that the number of board meetings held during the fiscal year should be disclosed in the annual report. $32 \%$ of the companies claim to do this without actually disclosing the number of meetings. Quite often the normal meeting schedule is presented, but the companies fail to deliver the exact number of meetings held.

\section{[INSERT FIGURE 5]}

Continuing to board composition, the overall scores are quite high, but for two of the recommendations in the graph above in figure 5 , a large number of the companies have chosen to deviate.

For 5.8.1, regarding the adoption of a retirement limit for board members, $42 \%$ of the companies have chosen to deviate. A total of $27 \%$ explain well why this approach is chosen. $15 \%$ do not put forth arguments beyond stating that a retirement age is not installed. 
For 5.9.1, where the main suggestion is that board members should be up for election each year, this is not followed by $22 \%$ of the companies. A total of $21 \%$ of the companies have a reasonable explanation for this practice, typically related to the need for board continuity.

\section{[INSERT FIGURE 6]}

Chapter 6 in the Danish Code contains quite specific recommendations concerning remuneration of top managers. These recommendations must be seen in combination with the rules in the Danish Company Act $\$ \mathbb{S}$ 138-139 and in particular in the many rules that cover executive managers who have a substantial influence on the risk profile of financial firms. The main objective of these rules is to foster sound risk taking, linking it more closely to a firm's business strategy by imposing quantitative restrictions on the variable remuneration component. Moreover, the rules in the Companies Act require that the general policies for incentive contracts are approved at the general meeting and thereafter disclosed.

Nevertheless, chapter 6 regarding remuneration is quite substantial, with a total of 15 specific recommendations. This is also a chapter where it is not straightforward in many instances to make completely balanced judgments about the different companies' practices. For instance, $13 \%$ do not have a remuneration policy as recommended by 6.1.1. By implication, it is therefore more difficult to make an assessment of the content of a non-existent policy in the following recommendations. However, there is a tendency for companies who claim not to have a remuneration policy to address several of the specific remuneration recommendations.

Figure 6 shows that $86 \%$ of the companies have adopted a remuneration policy for the two management bodies, but it is a bit surprising that $10 \%$ comply poorly as the issue of a remuneration policy has attracted a lot of attention from shareholders and the media. Figure 6 also shows that $6 \%$ explain poorly regarding the remuneration policy and especially any changes to the policy approved at the general meeting.

Recommendation 6.1.3 states that the remuneration policy includes a thorough description of the remuneration components. The vast majority of firms comply $(86 \%)$ or explain $(7 \%)$ but there are $3 \%$ who explain poorly and $5 \%$ who comply poorly, respectively. One notices the same proportion regarding the criteria and reasons for components in 6.1.4. These two recommendations are important as they offer investors guidance on what 
determines managerial remuneration so that investors may assess the effectiveness of a firm's incentive contracts. This knowledge is vital when investors seek to compare the costs of the incentive contracts (which must be disclosed) andwhich are expected to cause an increase in managerial effort.

The criteria and components are by nature firm specific. To illustrate, Novo Nordisk's executive remuneration is compared with a benchmark of large Danish firms as well as with a benchmark of comparable European pharmaceutical firms. In contrast, A.P. Møller Mærsk distinguishes between cash bonus and share options, where the criteria in the former case depends on the achievement of specific financial goals for one or more business areas, whereas this is not true in the latter case. Instead, it is left to the discretion of the Board of Directors remuneration committee. Moreover, in Danske Bank, both financial as well as non-financial goals are included in the remuneration packages of the executive directors.

Chapter 6.1 deals with specific criteria of the remuneration policy for executive management and the supervisory board, but does not say anything about disclosure. Disclosure is dealt with in chapter 6.2 . The challenge is that a company can claim that the remuneration policy is in line with the recommendations, and at the same time choose not to disclose the policy.

\section{[INSERT FIGURE 7]}

Figure 7 shows that firms on a general level tend to comply/explain quite often although there are certain $\% \%$ ages that could be improved: for example, in the case regarding restrictions on variable pay, $3 \%$ explain poorly and $6 \% \%$ comply poorly. Recommendation 6.1 .5 argues for limits to be set on the variable components of the total pay package emphasizing the linkage between expected risks and the value creation for shareholders in the short and long-term.

The Committee recommends that there is clarity about performance criteria and measurability for award of variable components. This is important as in some cases even in large firms, executive managers' variable remuneration sometimes depends on unclear sustainability indices that cannot be given a clear interpretation and are influenced by random factors such as measurement, methodology etc. 
Therefore, there is room for some improvement regarding this issue. Figure 7 also shows that nearly all firms comply $(92 \%)$ with the recommendation that members of the supervisory board do not receive share or warrant programs. This is important as there might be a conflict of interest if a supervisory board may grant itself e.g. share options on very favourable terms such as low exercise price, short exercise period, etc. A very few firms explain that despite this inherent risk, supervisory members also receive share incentive contracts, but shareholders must remain alert in these situations.

It is recommended in 6.1.7 that share-based remuneration is established as roll-over programs meaning that options are granted periodically and should not be exercisable earlier than three years from the date of grant. This is necessary to secure long-term incentives.

Most firms (78\%) have implemented a claw back provision c.f. 6.1.8. meaning that companies should be able to reclaim variable components that were paid on false grounds i.e. based on data, which proved to be manifestly misstated. Although, hard law supplements this recommendation, it is striking that $12 \%$ of the firms explain why they do not have such a provision, and more importantly, $8 \%$ explain only poorly, suggesting room for improvement regarding the lack of claw back provisions. On the other hand, all $(99 \%)$ of the firms either comply or explain that termination payments should not amount to more than two years of compensation, which clearly makes sense c.f. 6.1.9.

\section{[INSERT FIGURE 8]}

Figure 8 displays the recommendations regarding disclosure of the remuneration policy. In order for shareholders to exercise their power at the AGM in relation to remuneration policy it is necessary that the information is clear and easily understandable in an accessible way. Therefore, it is surprising that $8 \%$ of the companies explain poorly and that $15 \%$ comply poorly c.f. 6.2 .1 . This impression is improved when it comes to the chairman's explanation and justification in his statement at the general meeting where the compliance/explanation rate is higher i.e. $79 \%$ and $6 \%$, respectively.

The issue of disclosing total individual pay has been much debated and several firms have decided only to disclose the total remuneration for the entire supervisory board and executive board separately arguing that 
information about individual salary is less relevant for shareholders and investors. Therefore, it does not come as a surprise that the comply or explain disclosure rate is as low as "only" 57\%. A large proportion of firms (11\%) explain adequately why they have deviated from the recommendation.

The Danish Committee emphasises that openness and transparency about all important issues regarding the principles for total remuneration is essential. Therefore, there is room for some improvement regarding individual executive pay that should be reasonable and reflect independent performance, responsibilities and long-term value creation in the company. A possible explanation why the compliance/explanation rate is low might reflect fear among the members of the supervisory board that the media may initiate a personal campaign against the firm executives in which material details of the remuneration package are left out so that the media coverage is incomplete. However, the fact that CEOs of large listed firms may be able to justify their remuneration due to their performance in the public stands contrary to this argument. Most interestingly, for recommendation $6.2 .1,15 \%$ of firms who claim to comply with an easily understandable remuneration policy are, in practice, not complying. These companies fail to put forth remuneration policies that give the interested party a clear and concise overview of the content and arguments for why the remuneration policy is adopted as it is.

Regarding 6.2.3, as much as $21 \%$ fail to argue reasonably for why they do not disclose individual remuneration. For a great deal of these companies, board remuneration is disclosed individually, but individual remuneration for the executive management is not disclosed. A common argument used by this group is that individual remuneration will not provide additional information to investors.

The vast majority of firms comply/explain disclosure (90\%) in relation to the most important aspects of retention and severance programmes disclosed in the annual accounts. Such clauses may be triggered by "change of control" clauses, insurance or pension shemes. As these financial benefits are often quite substantive and reflect remuneration costs, information about these issues is important for investors and shareholders.

The compliance/explanation rate is also relatively high regarding board remuneration approved by the general meeting. Members of the supervisory board often receive a fixed fee, whereas the vice chairman and chairman usually receive double and triple this fee, respectively. It is very rare that the members of the supervisory board 
receive various share options or warrants which is a sound policy, as there is a potential risk of self-dealing if the supervisory board can decide on its own terms on such a share program.

Regarding 5.9.1, where the main content is that each board member should be up for election each year, this is not followed by $22 \%$ of companies. As many as $21 \%$ have a reasonable explanation for this practice, typically related to the need for board continuity.

\section{[INSERT FIGURE 9]}

As figure 9 shows, only a limited number of companies have been given a score of 0 . It is more important how many companies have chosen not to comply with these recommendations, especially 5.10 .7 and 5.10.8, which related to organizing a nomination and remuneration committee, respectively. Several companies that have chosen to deviate have not made very strong arguments for their choice.

However when assessing these recommendations, the decision was made not to give 0 scores to these companies, but rather to detect whether or not committees were established. The reason for this decision is that listed Danish companies do not have boards sufficiently large enough to justify establishing separate committees. This argument seems to be strengthened by the fact that 5.10 .2 recommends that the majority of committee members are independent. If a board consists of six members in total, and half of these are independent, then each independent member must take part in at least two committees. This raises the question of whether Danish boards are too small, or whether board committees are perhaps not appropriate considering the size and structure of most Danish listed companies and their respective boards.

\section{[INSERT FIGURE 10]}

It is recommended that the supervisory board evaluates its performance and achievements as a group and individually (5.11.1) evaluates the executive board (5.11.3) and that the Chairman and the CEO jointly evaluate the cooperation between the supervisory and executive board (5.11.4). All these recommendations emphasize that the evaluations are done annually. The overall impression is that the companies follow these recommendations (see figure 10). 
Those who have chosen to deviate from these recommendations are generally not deviating from evaluations per se, but they have often chosen to treat evaluations more as steps in a continuous process, and as a less formal procedure than the recommendations suggest.

5.11.2 recommends that the procedure and outcome of the performance evaluation of the supervisory board (5.1.1) is disclosed in the annual report. As much as 33\% claim to be complying, but when assessing this statement, it turns out that the level of disclosure is rather poor. In most instances, companies just state that an evaluation has taken place, without disclosing how it was conducted, and not revealing the results. $30 \%$ do not justify why they do not disclose information about the board evaluation.

A relatively large number of companies argue that since their evaluations are continuous and not formalized, it is impossible to account for the procedures and results in their annual report. Such arguments were not found to be sufficient. As mentioned, the two specific recommendations in the Danish Code Chapter 7 regarding financial reporting score $100 \%$ so I have not displayed these results.

\section{[INSERT FIGURE 11]}

Figure 11 displays the recommendations in Chapter 8 of the Code regarding risk management and internal control, which are areas where performance is generally very high. The annual reports contain much more information about risks, the potential impacts of these risks, and how the companies are working to mitigate or reduce the impact of these risks. Figure 11 shows that all firms have identified the most important business risks associated with the realization of the companies' strategy and overall goals. This is also the case for the executive board report to the supervisory board on the development within the most important areas of risk and compliance. This enables the supervisory board to track development and to make necessary decisions i.e. to identify key risk indicators for the firm's top risks as well as to formulate risk-mitigating strategies.

Recommendation 8.2.1 states that companies should decide whether or not to establish a whistleblowing scheme. This is the only recommendation in Chapter 8 where a sizeable number of the companies have chosen to deviate. However, in practice there is really no difference between complying with this recommendation and 
not complying, as companies are merely encouraged to make a decision; to implement a whistle-blowing scheme or not.

There may be pros and cons associated with implementing a whistleblower policy. One the one hand, such an initiative may signal a lack of trust towards the employees from the side of executive management, but if implemented well, such a system may deter serious ethical misconduct or illegal actions by key employees e.g. fraud, bribery, or anti-competition violations. Nearly all firms report about the firm's management practice regarding business risks.

\section{REGRESSION RESULTS}

This article relies on two widely-used performance measures -i.e. ROE and ROA -in which the former measures value creation for the shareholder whereas the latter measures the return in relation to the total amount of resources or assets in a firm. This study conducts the following cross sectional regression where both performance measures serve as dependent variables while the firm's corporate governance comply or explain disclosure - i.e. the CG variable—serves as an explanatory variable on the right side of the equation.

$$
\text { Performance company }_{i}=a^{*}+\beta^{*} \text { CGscore } i+\sum \beta^{*} \text { controlvariables }_{i}+\mu
$$

Control variables include: industry dummies, share segments, firm size (LnMarketCap), as well as a dummy variable if a firm has proportionality between ownership and control (i.e. "one share - one vote"). If a firm does not have dual class voting shares, voting right ceilings, or ownership caps, the dummy variable entitled "one vote - one share" equals one, otherwise it equals zero. The reason for including this variable is that there has been a debate on whether deviations from proportionality between control and voting rights sustain or harm shareholder value, see Rose (2008) for a description and analysis. Since deviations from the one share - one vote principle are widespread in Denmark, it has been included as a relevant control variable.

Multicollinearity may be a problem if the explanatory variables are highly correlated. Technically, in cases of high collinearity the standard errors increase dramatically, thereby making the $t$ values smaller. As a result, one will increasingly accept the null hypothesis that the relevant true population coefficient is zero (see Gujarati (1992) 
for a pedagogical description). However, as the table in the appendix shows, this is not the case, as the correlation coefficients are relatively quite low.

All financial data has been obtained from Bloomberg. The appendix shows descriptive statistics. The equation is estimated by OLS and the residuals have all been examined graphically in order to see if they satisfy the four conditions regarding the residuals. It turns out that they all do, including the assumption about heteroscedasticity (i.e. non-constant variance of the residuals) which sometimes presents a problem in cross-sectional regressions.

\section{[INSERT TABLE 2]}

Tables 2 and 3 show the regression results where ROE and ROA serve as dependent variables. The coefficient for the variable CG-ScoreTotal is positive and significantly different from zero in table 2. A coefficient of 1.3 means that increasing the comply or explain disclosure number by one recommendation, increases the ROE by $1.3 \% \%$ age points. Increasing corporate governance comply or explain disclosure on a general level is therefore associated with an increasing ability to create a return for shareholders. The control variables One-share-onevote and firm size are also positive and significantly different from zero. This is also the case for the industries: Financials, Consumer and IT, which are measured relative to the Industry category. The explanatory power of the estimated equations is relatively low i.e. around $20 \% \%$, which is not uncommon in cross-sectional regressions where the dependent variable is firm performance.

Moreover, when breaking down the compliance categories, table 2 shows that the variable CGScoreBoardComposition is not significantly different from zero. In other words, this variable has no explanatory power regarding ROE. However, this is not the case for the variable CG-ScoreRemuneration which is positive and significantly different from zero. This means that increasing the degree of corporate governance comply or explain disclosure within the recommendations on managerial remuneration is associated with a higher ROE. If one looks at the relationship between the recommendations on risk management and internal controls and ROE, table 2 documents that there is no significant relationship.

[INSERT TABLE 3] 
Table 3 depicts similar regression results, now with ROA as the dependent variable. Notice that increasing the general level of corporate governance comply or explain disclosure is associated with ROA as the variable CGScoreTotal is positive and significantly different from zero although the coefficient is a bit lower than previously observed. One notices that the variables One-share-one vote, Consumer, and IT are also positive and significant in the first equation.

Contrary to the previous table regarding ROE, table 3 shows that the variable CG-ScoreBoardComposition is now positive and significantly different from zero. The control variable Healthcare in equation 2 is negative and significant meaning that firms belonging to the healthcare industry in 2010/2011 have lower ROA values.

On the other hand, the variable CG-ScoreRemuneration is no longer significantly different from zero as in the previous table where ROE served as the dependent variable. Finally, the last CG score i.e. CG-ScoreAudit is not significantly different from zero either.

Multicollinearity may be a potential problem if the correlation between some of the variables is high. With perfect collinearity the standard errors go to infinity, which means that the columns of the explanatory variables are linearly dependent which makes estimation impossible. However, the correlations reveal that they are only moderate and not high enough to indicate collinearity (the correlation table is not displayed due to limitations of space considerations).

This article's results are in line with other studies such as Renders (2012), Sanderson (2010), and Seidl (2013). Most studies rely on market as well as book values to measure performance. The reason for only using book values is that it is quite difficult to adjust for firm risk. Ideally, one would use a measure such as Jensen's alpha which uses beta values, but the problem is that such beta values may not really capture the market risk due to low trading and illiquidity. There are relatively many listed companies on the Danish stock exchange, but several smaller firms are traded infrequently. Therefore, this study relies on two well-known accounting performance measures i.e. ROA and ROE which are also used frequently in the literature.

However, more importantly, all studies rely on how firms communicate their corporate governance policy. As a consequence, this may represent a potential bias. To illustrate, if a firm communicates that it has conducted a board evaluation, it is impossible to assess the quality of such an activity. This means that it is hard to verify 
whether a company in fact acts as it communicates to the public. As a consequence, one should not overstate the performance findings.

This article's findings show that there is a positive significant relationship between firm performance and corporate governance compliance. Specifically, the model outlined in section 7 assumes that the causation runs from a firm's corporate governance score to performance. However, one cannot rule out that the causation runs in the opposite direction i.e. if a firm's financial performance is increasing this may result in a higher degree of corporate governance comply or explain disclosure. The key to address this problem is to rely on suitable “instrumental variables" see Himmelberg et al. (1999). However, it is hard to find good instruments in practice, especially when firm performance is part of the equation, see e.g. Wooldridge (2002) for a comprehensive description.

One might consider using lagged variables as instruments for current values. However, this is difficult since it is very comprehensive work to gather and collect information about a firm's corporate governance compliance. In addition, there have been changes in the recommendations that make it problematic to compare them over time. Furthermore, one cannot rule out that there are confounding effects, especially in relation to ownership data. For example, the existence of family ownership, foreign ownership, as well as blockholder ownership would likely have an effect on corporate governance practices and performance.

Unfortunately, the Danish accounting rules only require ownership above $5 \%$ as well as changes of $5 \% \%$ to be made public, so it is usually impossible to identify all large shareholders exact ownership size in a given company. Often companies only disclose that $\mathrm{X}, \mathrm{Y}$ and $\mathrm{Z}$ own more than five $\% \%$. Foundation ownership is common in Denmark and foundation ownership in listed firms is more frequently made public due to voluntary ownership disclosure policies by the foundations. However, as shown by Thomsen and Rose (2004), it is virtually impossible to find a significant performance impact from foundation ownership. This is also the case regarding board characteristics, see Rose (2005).

Moreover, given the expected time lag between implementation of corporate governance practices and when the firm accounting performance "kicks in" - one may also use lagged measures for accounting performance. Theoretically, better governance should then have a direct impact (as measured in terms of accounting performance), but also in terms of financial market performance - as investors see the firm as less risky/more 
predictable and thus, demand a lower cost of capital (which then would raise the value of the firm). As a consequence, the same regression equations have been re-estimated using lagged variables (one-year lag only) with respect to ROA and ROE. However, none of the variables are significantly different from zero on a five $\% \%$ level (only ROA lagged one year has a significance level of 0,087 on TotalCG score). Therefore, the results are not shown in the article, but the findings underline that it is a challenge to obtain strong significant relations between firm performance and corporate governance comply or explain disclosure.

In addition, all regression equations have been re-estimated using Tobin's Q which is a highly-used performance measure in corporate governance studies. This study uses a modified version of Tobin's Q since it is difficult to obtain information about the market value of debt. Instead, the following definition is used: market value of equity/book value of assets (mean value equals 1,18).

However, again there are no significant relationships between corporate governance compliance and firm performance on a 1 or $5 \% \%$ significant level.

Even though the above results show that there is a positive relationship between increased corporate governance comply or explain disclosure and financial performance, it should be mentioned that in order to establish a more solid link, the data should include several years. However, since the recommendations have changed during the years, this is by definition extremely difficult. Moreover, the findings are related to previous evidence found e.g. in Tariq and Abbas (2013) who also rely on the same financial performance measures in their sample of Pakistani firms.

\section{DISCUSSION \& CONCLUSION}

As the article demonstrates, Danish firms show the lowest degree of comply or explain disclosure within the categories: board composition, remuneration policy, as well as within risk management and internal controls despite the fact that overall comply or explain disclosure with the Danish code's many recommendations is relatively high. The reason may be that the recommendations within these three categories are viewed to be more burdensome compared to the code's other categories. 
This article analyses disclosures made under a relatively new disclosure rule (cf. insertion of a section $107 \mathrm{~b}$ Financial Statements Act (årsregnskabsloven). One may argue that many companies were not fully aware of the recently-introduced mandatory character of "comply or explain", or that they were not yet used to issuing corporate governance statements, which could have significantly influenced the quality of disclosure.

To illustrate, the recommendations within remuneration policy have been highly debated following the financial crisis. The public as well as investors are now showing more concern if granted incentive contracts do not contribute to sound risk taking and long-term value creation. Institutional investors have become more active in confronting poor or inadequate corporate governance policies in listed firms. Therefore, we would in the future expect that institutional investors will focus more on poor explanations or wrongful claims of compliance.

Furthermore, there are several methodological challenges when trying to measure or evaluate a firm's degree of corporate governance compliance. National codes do not only vary in size and scope, but different institutional and legal frameworks make it hard to compare comply or explain disclosure across jurisdictions. Nevertheless, there is reason to believe that future academic work will focus on this particular area of research in order to evaluate the effect of soft law across countries.

An important aspect that complicates the analysis is that corporate governance recommendations may change over time. New recommendations may be introduced while others may be withdrawn. To illustrate, in the first code in Denmark, board diversity was not mentioned in a single word. This has changed. The first code recommended that the board should not consist of more than six shareholder-elected members. This has now been moderated so that the board must now consider if the supervisory board consists of so many members to allow constructive debate and effective decision-making processes which enable all members to play an active role. The role of employee members was not mentioned in the first code, but in the second version, the company is now expected to state that the employee members are by construction not independent and therefore the Danish rules for employee-elected board members should be explained.

Furthermore, since the number of recommendations has changed as well as has the content of the code, it is very difficult to construct longer time series in order to use panel data estimation. 
Another methodological issue of relevance is whether one should weigh the individual recommendations after their relative importance. This might be appealing, as all recommendations cannot by construction be equally important. How — and using what criteria_-should one weigh them? This is extremely difficult to answer and such an approach may also entail a higher degree of arbitrariness.

The article finds some evidence of increased comply or explain disclosure within the Danish recommendations as well as regarding board composition and managerial remuneration and it association with positive firm performance. This is not the case in relation to the recommendations on risk management and internal controls. However, it should be acknowledged that these topics are important not only for Danish firms, but to all firms in the world. The challenge is that the number of recommendations is limited to four separate recommendations. The level of comply or explain disclosure is also quite high.

As a consequence, one cannot conclude that risk management and internal controls are not central topics for a board to discuss and address. The reason is that the methodology used analyses a change in performance given an increase in the overall score within these topics.

One may take into account the fact that lower compliance scores could be due to the ease at which investors can verify information. Compliance may be higher, where information is more difficult to verify, while disclosures may be more carefully undertaken, when information can be scrutinized easily by external observers. For example, if compliance with board composition is low, this could simply be due to the fact that board composition is relatively easy to verify from the outside.

It seems hard to deny that a higher degree of comply or explain disclosure with a set of best practice recommendations in combination with a true desire to improve a firm's corporate governance structure can add value. The critical issue is how an outsider can verify this. One possibility could be to measure and carefully observe total external communication from a firm to its stakeholders. Another consideration is whether comply or explain disclosure is really followed up by action in combination with a professional approach in the boardroom.

This clearly depends on the board members collective mindset. They must realize that best practice, which in some cases can be supported by academic research, actually adds value. If corporate governance is only 
considered to be a mechanical tick-the-box exercise, the entire foundation for working seriously with the quality of corporate governance of the firm will be jeopardized. However, in order to strengthen investor confidence, national code authorities/committees should be more active in penalizing poor explanations and cases where firms wrongfully state that they comply with a specific recommendation.

Ultimately, we need more research on how we measure the degree of comply or explain disclosure and its impact on firm value, especially because this study has shown that there is not always a strong significant relationship between firm performance and corporate governance comply or explain disclosure. In this connection, there are a number of methodological research questions that should be addressed in the future. This article has shown that there is a positive correlation between the degree of comply or explain disclosure and performance, but we need further evidence as well as country specific studies to make hard conclusions regarding this important issue.

\section{Acknowledgements.}

I am very grateful to Nicolai Søpstad for assisting in the careful data collection and to Anne Sluhan as well as Luisa Murphy for English text editing. I am also grateful for very useful comments by two anonymous referees. 


\section{References}

Adams, Renee, Heitor Allmeida and Daniel Ferreira (2005) "Powerful CEOs and their impact on corporate performance", Review of Financial Studies, 18: 1403-1432

Aguilera, Ruth V., and Cuervo-Cazurra (2009), Codes of good governance, Corporate Governance. An International Review, 14, 3, 376-387

Akkermans, Dirk, Hans van Ees, Niels Hermes, Reggy Hooghiemstra, Gerwin Van der Laan, Theo Postma and Arjen van Witteloostuijn (2007), Corporate governance in the Netherlands: An overview of the application of the Tabaksblat Code in 2004, Corporate Governance: An International Review, 15, 6, 1106-1118

Alves, Carlos and Victor Mendes (2004), Corporate Governance Policy and Company Performance: The Portuguese case, Corporate Governance: An International Review, 12, 3, 290-300

Andres, Christian and Erik Theissen (2008), Setting a fox to keep the geese - Does the comply-or-explain principle work?, Journal of Corporate Finance, 14: 289-301

Arcot, Sridhar, Valentina Bruno and Antoine Faure-Grimaud (2010), Corporate governance in the UK: Is the comply or explain approach working?, International Review of Law and Economics, 30: 193-201

Beauwhede, Heidi Vander, and Marleen Willekens (2008), Disclosure on corporate governance in the European Union, Corporate Governance. An International Review, 16, 2, 101-115

Bebchuk, Lucian A., K. J. Martijn Cremers and Urs C. Peye (2011), “The CEO pay slice”, Journal of Financial Economics, vol. 102, iss. 1: 199-221

Becht, M and A. Roel (1999), Blockholding in Europe: An international comparison, European Economic Review, 42, $10-49$

Bhagat, Sanjai, Brian Bolton and Roberta Romano (2008), “The promise and peril of corporate governance indices", Columbia Law Review, 108, No. 8:1803-1878

Bozec, Richard, Mohamed Dia (2012). Convergence of corporate governance practices in the post -Enron period: Behavioral transformation or box-ticking exercise, Corporate Governance, 2, 234-256

COMMISSION RECOMMENDATION of 9 April (2014) on the quality of corporate governance reporting ('comply or explain') (2014/208/EU

Dyczkowska, Joanna (2012). Compliance of Polish publicly quoted companies with recommended practices regarding investor relations: An empirical study, Current Issues of Business and Law, 7(1), 46-66 
Fasterling, Björn (2012). Development of Norms through Compliance Disclosure, Journal of Business Ethics, 106: $73-87$

Fernandez-Rodriguez, Enrique, Silvia Gomez-Anson and Alvaro Cuervo-Garcia (2004), The stock market reaction to the introduction of best practices codes by Spanis firms, Corporate Governance: An International Review, $12,1,29-45$

Frey, L. R. et al. (1991), Investigating communication: An introduction to research methods. Englewood Cliffs, NJ Prentice-Hall

Garvey, Gerald T., Todd T. Milbourn, (2006) “Asymmetric benchmarking in compensation: Executives are rewarded for good luck but not penalized for bad", Journal of Financial Economics, 82: 197-225

Goncharov, Igor, Joerg Richard Werner and Jochen Zimmermann (2006), Does compliance with the German Corporate Governance Code have an impact on stock valuation? An empirical analysis, Corporate Governance: An International Review, 14, 5, 432-448

Grossman, Sanford and Oliver Hart (1983), "An analysis of the principal agent problem”, Econometrica, 51: $7-45$

Gujarati, Damordar (1992), Essentials of Econometrics, McGraw-Hill

Gutierrez, Isabel and Jordi Surroca (2012), Revisiting the corporate governance through the lens of the Spanish evidence, Journal of Management and Governance, 08, November

Jie Cai and Anand M. Vijh, (2007) "Incentive Effects of Stock and Option Holdings of Target and Acquirer CEOs", Journal of Finance, vol. 62, N. 4: 1891-1933

Jong, de Abe, Douglas V. DeJong, Gerad Mertens and Charles E. Wasley (2005), Journal of Corporate Finance, 11: 473-503

Hall, Brian and Kevin Murphy (2003) “The trouble with stock options", Journal of Economic Perspectives, 17: 49-70

Himmelberg, Charles, Glenn Hubbard and Darius Palia (1999), "Understanding the determinants of managerial ownership and the link between ownership and performance", Journal of Financial Economics, 53: 353-384

Holmstrom, Bengt (1979), "Moral hazard and observability", Bell Journal of Economics, 10: 74-91 
Hooghiemstra, Reggy and hans van Ees (2011). Uniformity as response to soft law: Evidence from compliance and non-compliance with the Dutch corporate governance code, Regulation and Governance, 5, 480-498.

Kaplan, Abraham, (1964), The conduct of inquiry: methodology for behavioral science, San Francisco: Chandler Publishing Co.

La Porta, Rafael, Florencio-de-Silanes, Andrei Shleifer and Robert W. Vishny (2000), Investor Protection and Corporate governance, Journal of Financial Economics, 58, 1-2, 3-27

Laux, Volker (2012)", Stock option vesting conditions, CEO turnover and myopic investment", Journal of Financial Economics, 116: 513-526

MacNeil, Iain and Xiao Li (2006), "Comply or explain", market discipline and non-compliance with the Combined Code, Corporate Governance: An International Review, 14, 5, 486-496

Masulis W, Ronald, Cong Wang and Fei Xie, (2007) “Corporate governance and acquirer returns”, Journal of Finance, Vol. 62, No. 4: 1851-1889

Mintz, Steven M. (2005), Gorporate governance in an international context: Legal systems, financing patterns and cultural variables, Corporate Governance; An International Review, 13, 5, 583-597

Morse, Adair, Vikram Nanda and Amit Seru (2011), “Are incentive contracts rigged by powerful CEOs?”, Journal of Finance, 76: 1779-1821

Nelson, James (2005), Corporate governance practices, CEO characteristics and firm performance, Journal of Corporate Finance, 11:197-228

Nowak, Eric (2008), The (Ir)relevance of the disclosure of compliance with corporate governance codes - evidence from the German stock market, see SSRN homepage http://papers.ssrn.com/sol3/papers.cfm?abstract_id=891106

OECD Steering Group on Corporate Governance, Corporate Governance and the Financial Crisis, Conclusions and emerging good practices to enhance implementation of the principles, 24. February 2010, see also the following link: http://www.oecd.org/daf/ca/oecdprinciplesofcorporategovernance.htm

Pass, Christopher (2006), The revised Combined Code and corporate governance. An empirical survey of 50 large UK companies", Managerial Law, Vol. 48, No. 5:467-478

Recommendations on Corporate Governance, Danish Committee on Corporate Governance, April 2010, see http://corporategovernance.dk/file/291826/committee_recommendations_april_2010.pdf

Renders, Annelies, Ann Gaeremynck and Piet Sercu (2012), Corporate-governance ratings and company performance: A cross-European study, Corporate Governance: An International Review, 18, 2, 87-106 
Rose, Caspar (2005), The Composition of Semi-Two Tier Corporate Boards and Firm Performance: The Danish Evidence, Corporate Governance: An International Review, Vol. 13,5, 691-701

Rose, Caspar (2008), A critical analysis of the "one share - one vote "controversy", International Journal of Disclosure and Governance, Vol. 5, No. 2: 126-139

Saad, Noriza Mohd (2010). Corporate Governance Compliance and the Effects to Capital Structure, International Journal of Economics and Finance, Vol. 2, 1: 105-115

Sanderson, Paul, David Seidl, John Roberts and Bernhard Krieger (2010), Flexible or not? The comply or explain principle in UK and German Corporate Governance, Working Paper No. 407, University of Cambridge, June 2010

Seidl, David, Paul Sanderson and John Roberts (2013), Applying the "comply-or-explain principle: discursive legitimacy tactics with regard to codes of corporate governance, Journal of Management and Governance, 17, 791-826

Shleifer, Andrei and Robert. W Vishny, (1997), A survey of corporate governance”, Journal of Finance, Vol. 52, iss. $2,737-783$

Shnitser, Natalya (2010). A Free Pass for Foreign Firms? An Assessment of SEC and Private Enforcement Against Foreign Issuers, The Yale Law Review, 119, 1638-1694

Sneller, Lineke and Henk Langendijk (2007), Sarbanes Oxley Sections 404 costs of compliance: a case study, Corporate Governance: An International Review, 15, 2, 101-111

Shrives Philip J., Niamh M. Brennan (2015), A typology for exploring the quality of explanations for noncompliance with UK corporate governance regulations, The British Accounting Review, 47: 85-99

Suchman, Mark C. (1995), Managing Legitimacy: Strategic and Institutional Approaches, The Academy of Management Review, Vol. 20, No. 3: 571-610

Talaulicar, Till and Axel v. Werder (2008), Patterns of compliance with the German corporate governance code, Corporate Governance: An International Review, 16, 4, 255-273

Tariq, Bin Yasir, and Zaheer Abbas (2013), Compliance and multidimensional firm performance. Evaluating the efficacy of the rule-based code corporate governance, Economic Modelling 35: 565-575

Tirole, Jean (2001), Corporate governance, Econometrica, 69, 1, 1-35

Thomsen, Steen and C. Rose (2004), Foundation Ownership and Financial Performance: Do Companies Need Owners? European Journal of Law and Economics 2004 Vol. 18, pp.343-364 
Tsipouri, Lena and Manolis Xanthakis (2004), Can corporate governance be rated? Ideas based on the Greek experience, Corporate Governance: An International Review, 12, 1, 16-26

Viral V. Acharya, Kose John, Rangarajan and K. Sundaram (2000), “On the optimality of resetting executive stock options", Journal of Financial Economics, 57, 65-101

Wooldrigde, Jeffrey M. (2002), Econometric analysis of cross section and panel data, MIT

Warning, Susanne (2011). Eigentümerstruktur und Aufsichtsratsverhalten. Eine Analyse anhand des Deutschen Corporate Governance Kodex. DBW, 71, 3: 265-279

Werder, v. Axel, Talaulicar Till and Kolot, Georg L. (2005), Compliance with the German Corporate Governance Code: an empirical analysis of the compliance statements by the German listed companies. Corporate Governance: An International Review, 13, 178-187

Zattoni, Alessandro and Cuomo, Francesca (2008). Why Adopt Codes of Good Corporate Governance? A Comparison of Institutional and Efficiency Perspectives, Corporate Governance. An International Review, 16, 1-15. 
TABLES \& FIGURES

Table 1.

\begin{tabular}{|lcc|}
\hline \multicolumn{1}{|c}{ Category } & $\begin{array}{c}\text { Total number of } \\
\text { reccomendations }\end{array}$ & $\% \%$ total \\
\hline Complies & 9.012 & $81,9 \%$ \\
Complies poorly & 499 & $4,5 \%$ \\
Explains & 998 & $9,1 \%$ \\
Explains poorly & 496 & $4,5 \%$ \\
\hline Sum & $\mathbf{1 1 . 0 0 5}$ & $\mathbf{1 0 0 , 0} \%$ \\
\hline
\end{tabular}

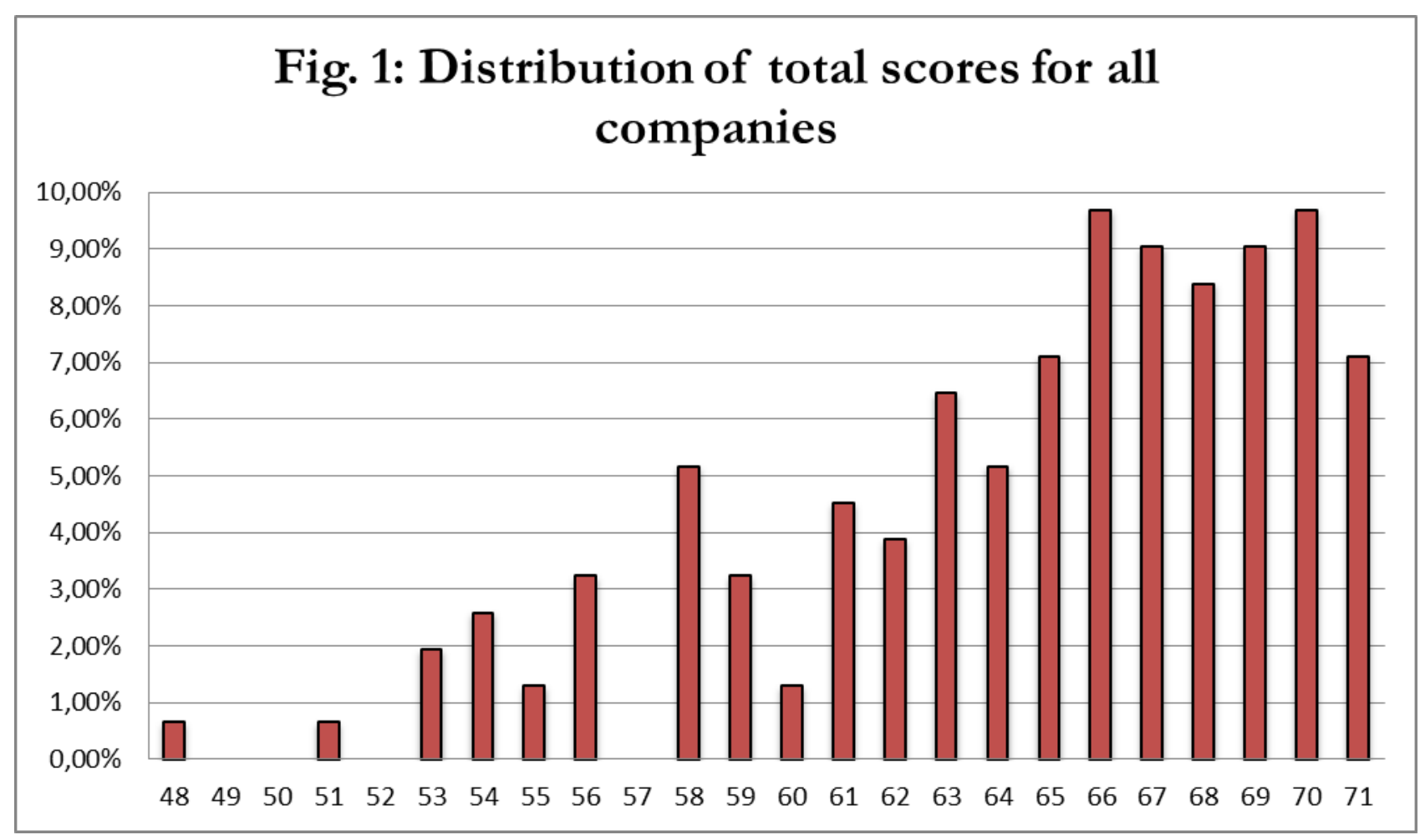




\section{Fig. 2. Distribution of scores on different stock indices}

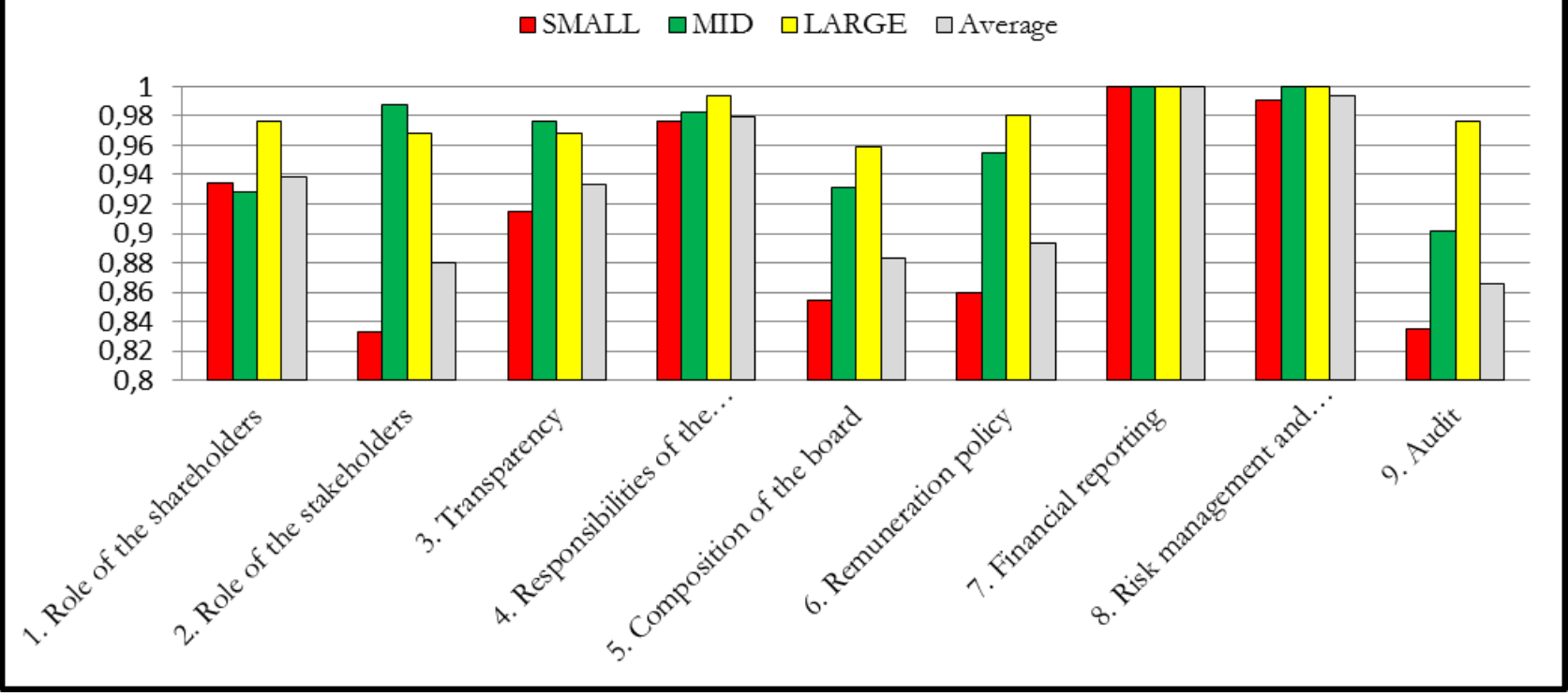

Fig. 3. Composition of the Board I

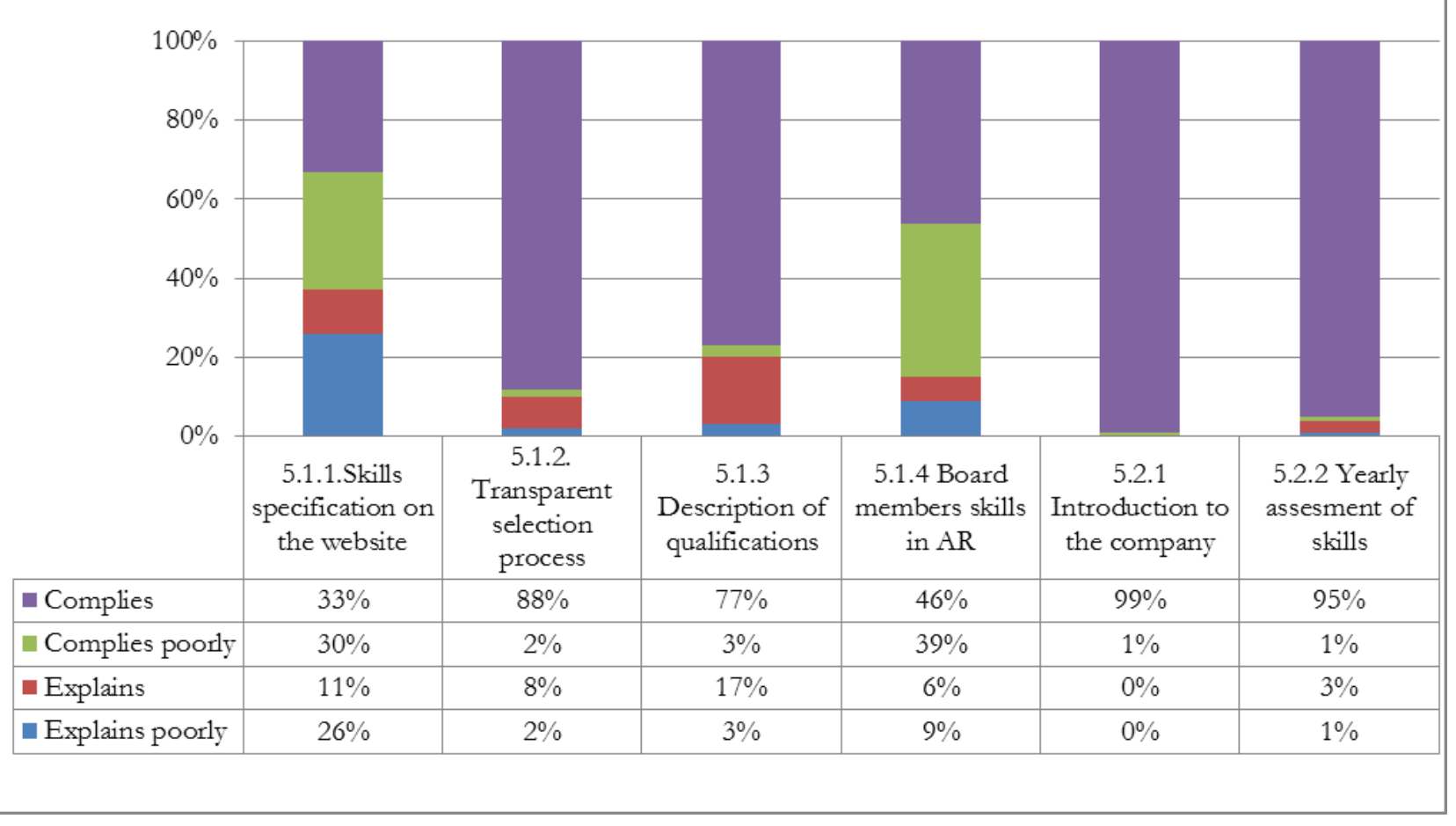




\begin{tabular}{|c|c|c|c|c|c|c|}
\hline \multicolumn{7}{|c|}{ Fig. 4. Composition of the board II } \\
\hline \multicolumn{7}{|l|}{$100 \%$} \\
\hline $95 \%$ & & & & & & \\
\hline $\begin{array}{l}90 \% \\
85 \%\end{array}$ & & & & & & \\
\hline $80 \%$ & & & & & & \\
\hline $75 \%$ & & & & & & \\
\hline $70 \%$ & & & & & & \\
\hline $65 \%$ & & & & & & \\
\hline $60 \%$ & & & & & & \\
\hline $55 \%$ & & & & & & \\
\hline $50 \%$ & $\begin{array}{l}\text { 5.3.1 Number } \\
\text { of members }\end{array}$ & $\begin{array}{l}\text { 5.3.2 Yearly } \\
\text { revision of } \\
\text { board size }\end{array}$ & $\begin{array}{l}\text { 5.4.1 Board } \\
\text { independence }\end{array}$ & $\begin{array}{l}5.4 .2 \text { Yearly } \\
\text { independence } \\
\text { review }\end{array}$ & $\begin{array}{l}5.5 .1 \\
\text { Employee } \\
\text { appointed }\end{array}$ & $\begin{array}{l}\text { 5.6.1 Meeting } \\
\text { freequency }\end{array}$ \\
\hline Explains poorly & $0 \%$ & $0 \%$ & $4 \%$ & $3 \%$ & $3 \%$ & $1 \%$ \\
\hline$\square$ Explains & $0 \%$ & $0 \%$ & $12 \%$ & $5 \%$ & $25 \%$ & $0 \%$ \\
\hline$\square$ Complies poorly & $0 \%$ & $0 \%$ & $1 \%$ & $2 \%$ & $10 \%$ & $32 \%$ \\
\hline$\square$ Complies & $100 \%$ & $100 \%$ & $83 \%$ & $90 \%$ & $63 \%$ & $66 \%$ \\
\hline
\end{tabular}

\begin{tabular}{|r|r|r|r|r|r|}
\hline \multicolumn{7}{|c|}{ Fig. 5 Composition of the board III } \\
\hline \\
\hline
\end{tabular}




\section{Figure 6. Remuneration Policy I}

\begin{tabular}{|c|c|c|c|c|}
\hline $100 \%$ & & & & \\
\hline $80 \%$ & & & & \\
\hline $60 \%$ & & & & 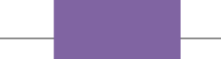 \\
\hline $40 \%$ & & & & \\
\hline \multicolumn{5}{|l|}{$20 \%$} \\
\hline $0 \%$ & $\begin{array}{l}\text { 6.1.1. Adoption } \\
\text { of remuneration } \\
\text { policy }\end{array}$ & $\begin{array}{c}\text { 6.1.2. Policy } \\
\text { approved at the } \\
\text { AGM }\end{array}$ & $\begin{array}{l}\text { 6.1.3 Description } \\
\text { of pay } \\
\text { components }\end{array}$ & $\begin{array}{l}\text { 6.1.4. Reasons } \\
\text { and criteria for } \\
\text { components }\end{array}$ \\
\hline Complies & $86 \%$ & $80 \%$ & $86 \%$ & $80 \%$ \\
\hline Complies poorly & $1 \%$ & $3 \%$ & $4 \%$ & $5 \%$ \\
\hline Explains & $3 \%$ & $11 \%$ & $7 \%$ & $12 \%$ \\
\hline Explains poorly & $10 \%$ & $6 \%$ & $3 \%$ & $3 \%$ \\
\hline
\end{tabular}

\section{Fig. 7. Remuneration policy II}

\begin{tabular}{|c|c|c|c|c|c|}
\hline \\
\hline \multicolumn{6}{|l|}{$95 \%$} \\
\hline \multicolumn{6}{|l|}{$90 \%$} \\
\hline \multicolumn{6}{|l|}{$85 \%$} \\
\hline \multicolumn{6}{|l|}{$80 \%$} \\
\hline $75 \%$ & & & & & \\
\hline $70 \%$ & & & & & \\
\hline $65 \%$ & & & & & \\
\hline & $\begin{array}{c}6.1 .5 \\
\text { Restricitions on } \\
\text { variable } \\
\text { components }\end{array}$ & $\begin{array}{l}\text { 6.1.6 No share- } \\
\text { based } \\
\text { remuneration for } \\
\text { the board }\end{array}$ & $\begin{array}{c}\text { 6.1.7 Share-based } \\
\text { remuneration as } \\
\text { roll-over } \\
\text { programmes }\end{array}$ & $\begin{array}{c}\text { 6.1.8 Claw-back } \\
\text { provision }\end{array}$ & $\begin{array}{c}6.1 .9 \\
\text { Termination } \\
\text { payments max } \\
\text { two years } \\
\text { remuneration }\end{array}$ \\
\hline Explains poorly & $3 \%$ & $3 \%$ & $3 \%$ & $8 \%$ & $1 \%$ \\
\hline$\square$ Explains & $10 \%$ & $5 \%$ & $6 \%$ & $12 \%$ & $8 \%$ \\
\hline$\square$ Complies poorly & $6 \%$ & $0 \%$ & $5 \%$ & $2 \%$ & $0 \%$ \\
\hline 口Complies & $81 \%$ & $92 \%$ & $86 \%$ & $78 \%$ & $92 \%$ \\
\hline
\end{tabular}




\section{Fig. 8. Disclosure of Remuneration policy III}

\begin{tabular}{|c|c|c|c|c|c|c|}
\hline \multicolumn{7}{|l|}{$100 \%$} \\
\hline \multicolumn{7}{|l|}{$95 \%$} \\
\hline \multicolumn{7}{|l|}{$90 \%$} \\
\hline \multicolumn{7}{|l|}{$85 \%$} \\
\hline \multicolumn{7}{|l|}{$80 \%$} \\
\hline \multicolumn{7}{|l|}{$75 \%$} \\
\hline \multirow{2}{*}{\multicolumn{7}{|c|}{$70 \%$}} \\
\hline \multirow{2}{*}{\multicolumn{7}{|c|}{$65 \%$}} \\
\hline \multirow{2}{*}{\multicolumn{7}{|c|}{$60 \%$}} \\
\hline & & & & & & \\
\hline \multicolumn{7}{|l|}{$55 \%$} \\
\hline $50 \%$ & $\begin{array}{l}\text { 6.2.1 Clear } \\
\text { and } \\
\text { understandabl } \\
\text { e, disclosed in } \\
\text { AR or web }\end{array}$ & $\begin{array}{c}6.2 .2 \\
\text { Explained and } \\
\text { justified in the } \\
\text { chairman's } \\
\text { statement }\end{array}$ & $\begin{array}{c}\text { 6.2.3 Total } \\
\text { individual pay }\end{array}$ & $\begin{array}{l}\text { 6.2.4 Total } \\
\text { value of } \\
\text { pension } \\
\text { schemes }\end{array}$ & $\begin{array}{l}6.2 .5 \text { Aspects } \\
\text { of retention } \\
\text { and severance } \\
\text { programmes } \\
\text { disclosed }\end{array}$ & $\begin{array}{c}\text { 6.2.6 Board } \\
\text { remuneration } \\
\text { approved by } \\
\text { AGM in } \\
\text { advance }\end{array}$ \\
\hline Explains poorly & $8 \%$ & $6 \%$ & $21 \%$ & $6 \%$ & $7 \%$ & $12 \%$ \\
\hline$\square$ Explains & $8 \%$ & $12 \%$ & $11 \%$ & $1 \%$ & $4 \%$ & $12 \%$ \\
\hline$\square$ Complies poorly & $15 \%$ & $3 \%$ & $10 \%$ & $4 \%$ & $3 \%$ & $1 \%$ \\
\hline$\square$ Complies & $68 \%$ & $79 \%$ & $57 \%$ & $89 \%$ & $86 \%$ & $74 \%$ \\
\hline
\end{tabular}

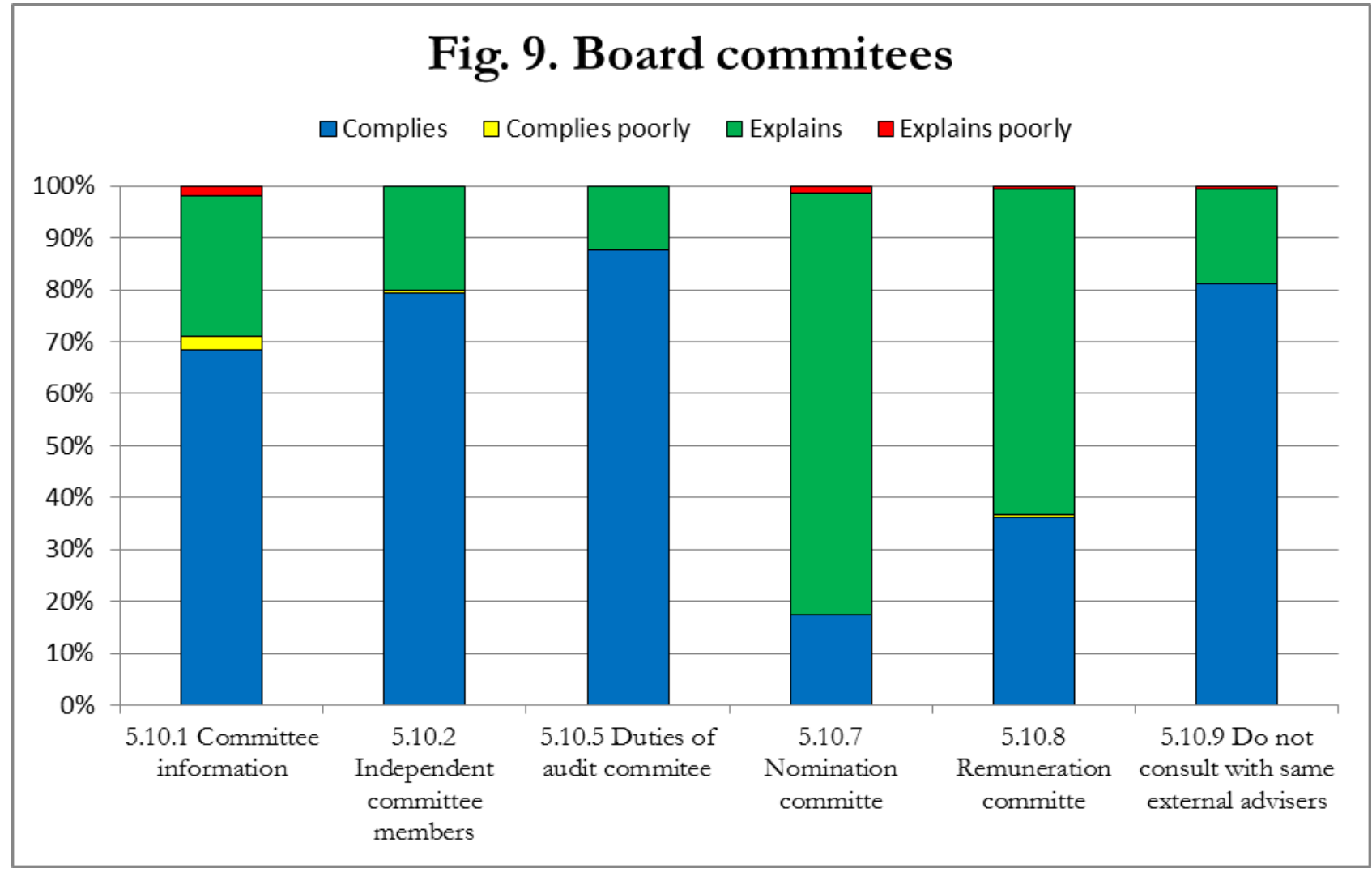




\section{Fig. 10. Borad evaluation}

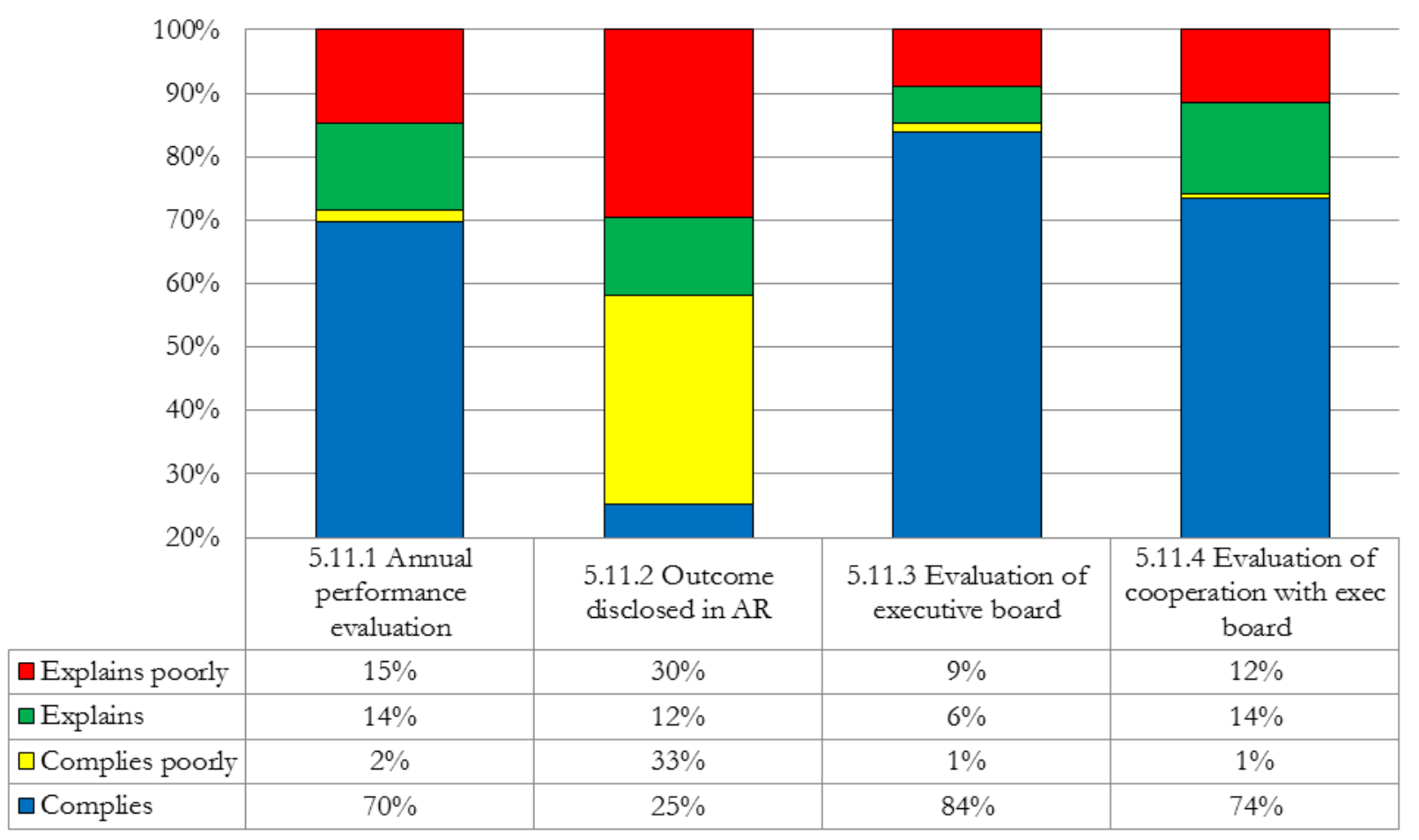

\section{Fig. 11: Risk management and internal control}

\begin{tabular}{|c|c|c|c|c|}
\hline \\
\hline $95 \%$ & & & & \\
\hline $90 \%$ & & & & \\
\hline $85 \%$ & & & & 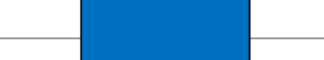 \\
\hline $80 \%$ & & & & 更 \\
\hline $75 \%$ & & & & \\
\hline $70 \%$ & & & & \\
\hline & & & & \\
\hline & $\begin{array}{l}\text { 8.1.1 Identification of } \\
\text { key risks }\end{array}$ & $\begin{array}{l}\text { 8.1.2 Report on risk } \\
\text { development and } \\
\text { compliance with } \\
\text { policies }\end{array}$ & 8.2.1 Whistleblowing & $\begin{array}{l}\text { 8.3.1 Openness about } \\
\text { risk management }\end{array}$ \\
\hline Explains poorly & $0 \%$ & $1 \%$ & $1 \%$ & $0 \%$ \\
\hline$\square$ Explains & $0 \%$ & $0 \%$ & $13 \%$ & $0 \%$ \\
\hline$\square$ Complies poorly & $0 \%$ & $0 \%$ & $0 \%$ & $1 \%$ \\
\hline$\square$ Complies & $100 \%$ & $99 \%$ & $86 \%$ & $99 \%$ \\
\hline
\end{tabular}




\section{Appendix:}

\section{A1. About the Danish Corporate Governance Code}

Denmark got its first recommendations in 2001, entitled "the Nørby report" after its chairman. Since then the recommendations have undergone revisions and adjustments e.g. in relation to the modernization of the Danish Company Act in 2010 as well as to the adaption of EU recommendations. The Committee emphasises the voluntary nature of the recommendations c.f. "Thus, non-compliance is not inconsistent with the spirit of the recommendations, but merely a result of the fact that the company has chosen a different approach. The markets must decide whether deviations are indeed justified.The Committee finds that self-regulation is the best form of regulation when it comes to corporate governance", see the Danish code (2010).

The recommendations fall into the following nine distinct categories:

- The role of the shareholders and their interaction with the management of the company

- The role of stakeholders and their importance to the company and the company's CSR

- Openness and transparency

- The tasks and responsibilities of the supervisory and executive board

- Composition and organization of the supervisory board

- Remuneration of the executive board

- Financial reporting

- Risk management and internal control

- Audit 


\section{The work of the Committee:}

The work of modernizing the Danish recommendations is carried out through the Danish Corporate Governance Committee that consists of representatives from the listed firms, investors, the stock exchange and advisors reflecting the interests of key stakeholders. Denmark relies on a two-tier board system, in which the supervisory board is to monitor and control the executive board. Furthermore, the supervisory board is also responsible fot formulating the firms overall strategy. Therefore one may speak of a semi-two tier board system, see Rose (2005) for an analysis of the Danish board system and its impact on firm performance. 


\section{A2. Descriptive statistics}

\begin{tabular}{|l|rrrrrr|}
\hline \multicolumn{7}{c|}{ Simple Statistics } \\
\hline Variable & $\mathbf{N}$ & Mean & Std Dev & Sum & Minimum & Maximum \\
\hline Score2010 & 155 & 64.56129 & 5.09658 & 10007 & 48.00000 & 71.00000 \\
CH_5 & 155 & 23.83226 & 2.45166 & 3694 & 16.00000 & 27.00000 \\
CH_6 & 155 & 13.38710 & 2.18432 & 2075 & 5.00000 & 15.00000 \\
CH_9 & 155 & 3.46452 & 0.66720 & 537.00000 & 1.00000 & 4.00000 \\
Share_structureOSOV & 155 & 0.40645 & 0.49276 & 63.00000 & 0 & 1.00000 \\
Mid & 155 & 0.21290 & 0.41069 & 33.00000 & 0 & 1.00000 \\
Small & 155 & 0.64516 & 0.48002 & 100.00000 & 0 & 1.00000 \\
ROE_2010 & 148 & -4.07858 & 35.78502 & -603.63047 & -217.89700 & 64.03121 \\
ROA_2010 & 151 & -1.94289 & 20.78387 & -293.37586 & -195.04418 & 24.98853 \\
LN_market_cap2010 & 149 & 6.21583 & 2.11278 & 926.15839 & 2.22953 & 12.84106 \\
\hline
\end{tabular}

\section{A3. Correlation Coefficients.}

\begin{tabular}{|c|c|c|c|c|c|c|c|c|}
\hline \multicolumn{9}{|c|}{$\begin{array}{l}\text { Pearson Correlation Coefficients } \\
\text { Prob }>|\mathrm{r}| \text { under H0: Rho }=0 \\
\text { Number of Observations }\end{array}$} \\
\hline & Score2010 & CH_5 & CH_6 & CH_9 & Mid & Small & OE_2010 & OA_2010 \\
\hline \multirow{5}{*}{ Score 2010} & 1.00000 & 0.84791 & 0.78296 & 0.53772 & 0.19072 & -0.43299 & 0.24595 & 0.25756 \\
\hline & & $<.0001$ & $<.0001$ & $<.0001$ & 0.0174 & $<.0001$ & 0.0026 & 0.0014 \\
\hline & 155 & 155 & 155 & 155 & 155 & 155 & 148 & 151 \\
\hline & 0.84791 & 1.00000 & 0.42811 & 0.43698 & 0.14534 & -0.37645 & 0.19817 & 0.26152 \\
\hline & $<.0001$ & & $<.0001$ & $<.0001$ & 0.0712 & $<.0001$ & 0.0158 & 0.0012 \\
\hline \multirow[t]{3}{*}{$\mathrm{CH}_{-5}$} & 155 & 155 & 155 & 155 & 155 & 155 & 148 & 151 \\
\hline & 0.78296 & 0.42811 & 1.00000 & 0.34365 & 0.20431 & -0.35740 & 0.24002 & 0.16703 \\
\hline & $<.0001$ & $<.0001$ & & $<.0001$ & 0.0108 & $<.0001$ & 0.0033 & 0.0404 \\
\hline \multirow[t]{3}{*}{ CH_6 } & 155 & 155 & 155 & 155 & 155 & 155 & 148 & 151 \\
\hline & 0.53772 & 0.43698 & 0.34365 & 1.00000 & 0.03960 & -0.23218 & 0.20174 & 0.25403 \\
\hline & $<.0001$ & $<.0001$ & $<.0001$ & & 0.6247 & 0.0036 & 0.0139 & 0.0016 \\
\hline \multirow[t]{3}{*}{$\mathrm{CH}_{-} 9$} & 155 & 155 & 155 & 155 & 155 & 155 & 148 & 151 \\
\hline & 0.19072 & 0.14534 & 0.20431 & 0.03960 & 1.00000 & -0.70129 & 0.02623 & 0.05391 \\
\hline & 0.0174 & 0.0712 & 0.0108 & 0.6247 & & $<.0001$ & 0.7517 & 0.5109 \\
\hline \multirow[t]{3}{*}{ Mid } & 155 & 155 & 155 & 155 & 155 & 155 & 148 & 151 \\
\hline & -0.43299 & -0.37645 & -0.35740 & -0.23218 & -0.70129 & 1.00000 & -0.23626 & -0.19903 \\
\hline & $<.0001$ & $<.0001$ & $<.0001$ & 0.0036 & $<.0001$ & & 0.0038 & 0.0143 \\
\hline \multirow[t]{3}{*}{ Small } & 155 & 155 & 155 & 155 & 155 & 155 & 148 & 151 \\
\hline & 0.24595 & 0.19817 & 0.24002 & 0.20174 & 0.02623 & -0.23626 & 1.00000 & 0.86407 \\
\hline & 0.0026 & 0.0158 & 0.0033 & 0.0139 & 0.7517 & 0.0038 & & $<.0001$ \\
\hline \multirow[t]{3}{*}{ ROE_2010 } & 148 & 148 & 148 & 148 & 148 & 148 & 148 & 148 \\
\hline & 0.25756 & 0.26152 & 0.16703 & 0.25403 & 0.05391 & -0.19903 & 0.86407 & 1.00000 \\
\hline & 0.0014 & 0.0012 & 0.0404 & 0.0016 & 0.5109 & 0.0143 & $<.0001$ & \\
\hline ROA_2010 & 151 & 151 & 151 & 151 & 151 & 151 & 148 & 151 \\
\hline
\end{tabular}

Share structure and Ln Market Cap are not displayed due to space limitations 
TABLE 2.

\begin{tabular}{|c|c|c|c|c|}
\hline Return on equity (ROE) as dependent variable & & & & \\
\hline Explanatory variables & 1. & 2. & 3. & 4. \\
\hline Constant & $-125,0 * * *$ & $-94,6 * * *$ & $-86,1 * * *$ & $-47,2 * *$ \\
\hline CG-Score-Total & $1,3 *$ & & & \\
\hline CG-Score-BoardComposition & & Not Sig. & & \\
\hline CG-Score-Remuneration & & & $3,0 * *$ & \\
\hline CG-Score- Audit & & & & Not Sig. \\
\hline One share-one vote (dummy variable) & $15,5^{* * *}$ & $15,4 * * *$ & $14,3 * * *$ & $12,5^{* *}$ \\
\hline Financials (dummy variable) & $16,2 * * *$ & $18,2 * * *$ & $16,0 * *$ & $20,0 * * *$ \\
\hline Consumer (dummy variable) & $17,7 *$ & $16,1^{*}$ & $17,4^{*}$ & \\
\hline IT (dummy variable) & $31,0 * * *$ & $30,7 * * *$ & $34,3 * * *$ & $35,0 * * *$ \\
\hline FirmSize(LnMarketCap) & $4,5 * * *$ & $5,0 * *$ & $5,4 * * *$ & $6,1 * * *$ \\
\hline Adj. $R$ square & 0,21 & 0,20 & 0,21 & 0,19 \\
\hline No of observations & 148 & 148 & 148 & 148 \\
\hline
\end{tabular}

Not Sig. $=$ Not significant. $*), * *)$, and ${ }^{* * *}$ ) significant on a 10,5 or $1 \% \%$ level, respectively. Only significant explanatory control variables are shown in the table. 
TABLE 3.

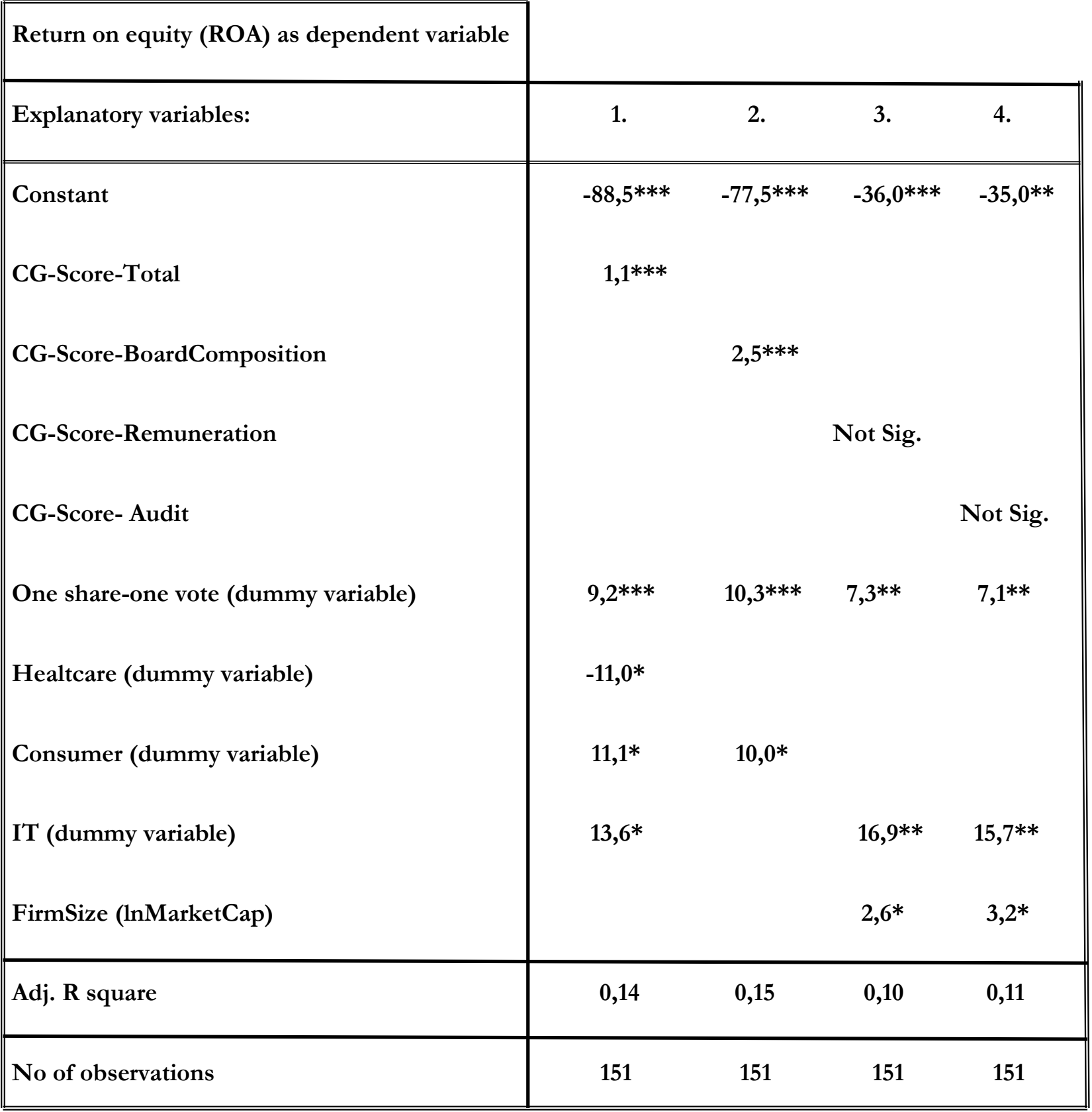

Not Sig. $=$ Not significant. $\left.*),{ }^{* *}\right)$, and $\left.* * *\right)$ significant on a 10,5 or $1 \% \%$ level, respectively. Only significant explanatory control variables are shown in the table. 
